\title{
Robert Chester Smith no Brasil: arte colonial e iconografia nas viagens de 1936 e 19471
}

Robert Chester Smith in Brazil: a field art history

https://doi.org/10.1590/1982-02672021v29e2

\section{SABRINA FERNANDES MELO²}

hitps://orcid.org/0000-000 1-5259-3360

Universidade Federal da Paraíba / João Pessoa, PB, Brasil.

RESUMO: Na primeira metade do século XX, houve uma convergência de interesses para a temática colonial, especificamente para a arte e arquitetura colonial brasileira, oriundas de diferentes países, como Estados Unidos, Portugal e Brasil. Dentre os inúmeros sujeitos, intelectuais e pesquisadores envolvidos, utilizo como fio condutor o historiador da arte Robert Chester Smith, que transitou entre os três países mencionados. $\bigcirc$ objetivo deste artigo é perceber como o projeto de catalogar e inventariar a arte e arquitetura colonial brasileira dialoga com o projeto para o patrimônio nacional. Discute-se a atuação de Robert Chester Smith em diversas cidades brasileiras, percorridas durante as viagens de 1937 e 1946. As viagens foram uma maneira de o historiador especializar-se em sua área de estudos por meio de pesquisas de campo, além de atender aos interesses culturais e políticos de instituições financiadoras de suas pesquisas. A bibliografia produzida no período que vai de 1937, ano de sua primeira visita ao Brasil, até 1946, ano de sua segunda visita, será interpretada pelos vieses cidades visitadas, tempo de estadia, instituições de apoio etc., e do ponto de vista teórico e metodológico, dos autores com os quais dialogou, os temas e arquivos pesquisados e fontes utilizadas.

PALAVRAS-CHAVE: Robert Chester Smith. Arte colonial brasileira. Iconografia.

\begin{abstract}
1. O artigo é fruto da tese de doutorado intitulada "Robert Chester Smith e o colonial na modernidade brasileira", defendida em 2018 no Programa de Pós Graduação em História da Universidade Federal de Santa Catarina - UFSC. A pesquisa foi desenvolvida com apoio do CNPQ - Processo $\mathrm{n}^{\circ} 140533 / 2013-3$

2. Professora Adjunta no Departamento de Artes Visuais da Universidade Federal da Paraíba e professora permanente no Programa Associado de Pós-graduação em Artes Visuais - PPGAV/ UFPB/UFPE. Doutora em História pela Universidade Federal de Santa Catarina, com pesquisa realizada na Fundação Calouste Gulbenkian em Lisboa, Portugal. E-mail: <sabrina.fmelo@ academico.ufpb.br>.
\end{abstract}


ABSTRACT: In the first half of the 20th century, there was a convergence of interests for the colonial theme, specifically for Brazilian colonial art and architecture, from different countries such as the United States, Portugal and Brazil. Among these countless subjects, intellectuals and researchers involved, I use the art historian Robert Chester Smith, who moved between the three countries mentioned, as the guiding thread. The purpose of the article is to understand how the project to catalog and inventory Brazilian colonial art and architecture dialogues with the project for national heritage. The article discusses the performance of Robert Chester Smith in several Brazilian cities, during the 1937 and 1946 trips. The trips were a way for the historian to specialize in his field of study through field research, in addition to serving the cultural and political interests of institutions that financed his research. The bibliography produced in the period from 1937, the year of his first visit to Brazil, until 1946, the year of his second visit, will be interpreted by the bias visited cities, length of stay, support institutions, etc. - and from the theoretical and methodological point of view with the authors with whom it dialogued, the themes and files searched and the sources used.

KEYWORDS: Robert Chester Smith. Brazilian colonial art. Iconography. 
"Quem era realmente Robert Chester Smith?". Com esse questionamento foi inaugurada a exposição Robert C. Smith 1912-1975 - A investigação na História de Arte, durante a $4^{\circ}$ Bienal Internacional de Arquitetura de São Paulo, em 1990. A exposição foi construída com base no espólio documental de Smith, doado por testamento à Fundação Calouste Gulbenkian (FCG), em Lisboa, Portugal, e enfatizou seus trabalhos dedicados à arte colonial brasileira. A seleção de imagens ocorreu em meio as mais de doze mil fotografias sobre arte e arquitetura luso-brasileira, produzidos por Robert Smith em viagens ao Brasil. Na mesma exposição, foram abordados aspectos de sua vida pessoal e as redes de relações estabelecidas por ele, evidenciadas em correspondências com intelectuais brasileiros, europeus e norte-americanos.

Em 2000, a mesma exposição foi realizada na capital porługuesa com o objetivo de lançar um olhar sobre a vida de um homem que "desembarcou em Lisboa antes da II Guerra Mundial e nunca mais parou de estudar o barroco colonial". ${ }^{3}$ A Bienal de Arquitetura e a exposição Robert (re)introduziram, no circuito brasileiro, o acervo desse historiador norte-americano, constantemente retomado para os estudos referentes ao período colonial brasileiro (1500-1822) e para a talha decorativa em Portugal.

Por intermédio do livro Robert C. Smith: a investigação na história da arte, organizado pela Fundação Calouste Gulbenkian, tive o primeiro contato com a obra de Robert Smith. O livro é uma coletânea de quinze artigos, escritos por diferentes historiadores da arte. Nele, há diversas imagens, fotografias, plantas e desenhos acumulados pelo historiador no decorrer de suas pesquisas. conjunto dos textos que compõem o livro apresenta um panorama dos trajetos investigativos de Smith, possibilitando uma visão geral de suas obras com base nas problemáticas lançadas pelos diferentes autores.

Grande parte dos artigos de Robert Smith sobre o Brasil foi reunida em duas publicações realizadas pelo Iphan com apoio da Fundação Calouste Gulbenkian, em 2012, ano de comemoração do centenário de Smith. Os dois volumes, organizados por Nestor Goulart Reis Filho, entraram para o conjunto das obras de referência do Iphan por intermédio de um projeto do arquiteto Luiz Fernando de Almeida, então presidente da instituição. Robert Smith e o Brasil: arquitetura e urbanismo (vol. I) é composto por nove artigos e textos introdutórios, elaborados por Beatriz Siqueira Bueno, José Pessôa e Renata Araújo. Reúne textos publicados em diferentes periódicos do Brasil, Portugal e Estados Unidos. Por estarem dispersos, seriam de difícil acesso à maioria dos pesquisadores, e, assim, o agrupamento dos textos permite a compreensão da: 
Amplitude dos campos de interesse daquele autor e alcance excepcional de seus estudos. Permite estudar sua trajetória como pesquisador, acompanhando em boa parte a construção de uma nova área de estudo, processo no qual teve papel destacado. ${ }^{5}$

O segundo volume, Robert Smith e o Brasil: cartografia e iconografia (vol. II) ${ }^{6}$ reúne dez artigos, nos quais o Smith utiliza a iconografia como principal fonte de pesquisa. A interpretação e o uso de imagens pictóricas, fotográficas, mapas e plantas ganham destaque e permitem interpretar sua produção artística como fotógrafo do Serviço do Patrimônio Histórico e Artístico Nacional - (Sphan), na acumulação de seu acervo pessoal e pela sua metodologia no trato das imagens como fonte de pesquisa histórica. A recente publicação dos volumes pelo Iphan revela uma retomada da produção de Robert Smith por parte dos pesquisadores, inserindo novamente sua obra no circuito acadêmico e organizando sua produção para pesquisas futuras.

Esse seria o início de um processo de "patrimonialização da memória" de Robert Smith no Brasil, uma trajetória iniciada por ele na década de 1930, retomada em 1990 e documentada em 2014, pelo Instituto do Patrimônio Histórico e Artístico Nacional, por meio da publicação e compilação de seus escritos a respeito do Brasil e por inúmeros pesquisadores interessados na trajetória de Smith e nas redes intelectuais traçadas pelo Sphan.

Na primeira metade do século XX, houve uma convergência de interesses para a temática colonial, especificamente para a arte e arquitetura colonial brasileira, oriundas de diferentes países, como Estados Unidos, Portugal e Brasil. Nesses três países, foram instauradas políticas de Estado e de aproximação cultural voltada para a temática colonial, amparadas por instituições, pesquisas, publicações e eventos em confluência de agentes e sujeitos que utilizaram o colonial com diferentes perspectivas. Dentre esses inúmeros sujeitos, intelectuais e pesquisadores envolvidos, utilizo como fio condutor o historiador da arte Robert Chester Smith, que transitou entre os três países mencionados.

Robert Smith realizou sua formação acadêmica em Harvard; interessou-se por diversas temáticas em seus estudos, como, por exemplo, ourivesaria, pintura votiva, azulejaria, mobiliário. Dedicou-se principalmente à arte e arquitetura luso-brasileiras. Smith estabeleceu vínculos de trabalho e pesquisa com os governos de seu país de origem (Estados Unidos), Portugal e Brasil apoiado financeiramente por instituições, como a American Council of Learned Societies, Guggenheim Foundation e Sphan.

As viagens associam-se ao deslocamento humano, à história das civilizações, ao turismo e, na perspectiva aqui analisada, à pesquisa, ao conhecimento do outro e às políticas de Estado. Desde o século XV, os Estados Nacionais financiaram viagens marítimas para regiões até então desconhecidas 
pelos europeus na tentativa de alcançarem lucro e riqueza. Já na segunda metade do século XVIII e primeira do XIX, muitas viagens buscaram conhecimento científico. França, Inglaterra e o Império Russo financiaram viagens com o fim de descrever o mundo geograficamente e conhecer os habitantes de diferentes regiões na tentativa de "relacionar as possibilidades econômicas dos continentes, sobretudo o africano". ? Já no período da Segunda Guerra Mundial e no contexto da política de Boa Vizinhança, ocorreu uma significativa oferta de bolsas de estudos por parte dos Estados Unidos para pesquisas na América Latina.

As viagens foram um dos recursos utilizados por Smith, amparado por políticas de Estado por parte dos Estados Unidos, Portugal e Brasil. Para se dedicar à sua área de estudos, coletar materiais para a formação de um acervo imagético e documental sobre arte e arquitetura colonial, produzir textos e livros sobre a temática e estabelecer uma rede de relações e contatos a partir de pesquisas de campo, além de atender aos interesses culturais e políticos das instituições financiadoras de suas pesquisas. As duas primeiras viagens de Smith ao Brasil aconteceram em 1937 e 1946; elas serão as balizadoras deste artigo, que tem como objetivo discutir suas impressões e atuações a partir do contato com monumentos, arquivos e pesquisadores de diferentes cidades brasileiras.

As viagens são interpretadas pelo viés geográfico - cidades visitadas por Smith, tempo de estadia, instituições de apoio, representantes nomeados pelo Sphan etc. - e, no sentido teórico e metodológico, ao abarcar os autores com os quais Smith dialogou, os temas e arquivos pesquisados, os tipos de fontes utilizadas, o conhecimento produzido sobre a região visitada, entre outros tópicos. Os relatórios de viagem produzidos por Smith em 1937 e 1947 são utilizadas não apenas para a compreensão do estado da arte dos estudos coloniais luso-brasileiros, mas para o entendimento das relações estabelecidas por Robert Smith no Brasil.

Nesses relatórios, datilografados em inglês e alocados no Acervo da Fundação Calouste Gulbenkian, Smith forneceu detalhes e impressões de suas viagens, como roteiros, datas, custos e contatos estabelecidos pelas diversas regiões do país. Essas anotações revelam muito sobre o pesquisador e o campo, sobre o que respalda e ampara a pesquisa. Por intermédio de suas viagens, Smith estabeleceu redes de colaboração nos níveis macro e micro. No nível macro, emergem as instituições financiadoras de bolsas de pesquisa, como a Fundação Guggenheim, a American Council of Learned Societies (ACLS); as instituições artísticas, como a Library of Congress e Museus; as instituições ligadas ao patrimônio, como o Sphan; e, por fim, as universidades, que figuraram como parte dessa dinâmica movida pela produção intelectual. 
Por sua vez, as publicações eram feitas em revistas e periódicos nacionais, como a Revista do Sphan, o Boletim do Centro de Estudos Históricos, nos livros encomendados pelas prefeituras e em revistas internacionais. No nível micro, afloraram redes de colaboração e amizade construídas por Smith, formando conexões que cruzaram fronteiras por meio de seminários, colóquios, críticas, comentários, textos, homenagens, cartas etc., que emergem as redes formadas por intelectuais nacionais e estrangeiros envolvidos nos debates sobre arte latinoamericana e luso-brasileira. Tais relações aglutinam ou afastam pares e mostram como os sujeitos se articulam no interior de um campo comum.

Com essas trocas e vinculações institucionais, Smith fortaleceu sua linha de pesquisa, direcionamento essencial nas primeiras décadas do século XX, visto que áreas como a História da Arte e da arquitetura ibero-americanas dos séculos XVI a XVIII e História da urbanização, seus principais motes de estudos, eram campos ainda em formação e, por isso, demandam pesquisas de campo, coleta de fontes e produção bibliográfica. Em busca disso, Smith esteve no Brasil por cinco vezes, nos anos de 1937, 1946, 1953, 1960 e 1969. Entretanto, o período analisado neste artigo contempla apenas as duas primeiras viagens - a de 1937, financiada pela American Council of Learned Societies (ACLS), e a de 1946, financiada pela Fundação Guggenheim.

\section{AOS "AMIGOS DO PATRIMÔNIO"}

A prática epistolar, percebida por Trebitsch ${ }^{8}$ como um "laboratório das amizades intelectuais", faz emergir relações entre os indivíduos que escrevem e aguardam respostas de suas cartas; uma via de mão dupla da qual emerge a relação com o tempo, uma característica típica das correspondências. As correspondências, papéis que dificilmente chegariam ao domínio público por serem geralmente descartadas, ganham uma nova perspectiva com os intelectuais que acumulam documentos, posteriormente doados a fundações culturais e/ou arquivos, como foi o caso das correspondências de Smith, doadas por ele à Fundação Calouste Gulbenkian.

Apesar de o enfoque incidir sobre as cartas trocadas com brasileiros, é indispensável mencionar que o acervo de Smith é composto por correspondências entre intelectuais de praticamente todos os continentes. As correspondências do arquivo relacionam-se ao seu trabalho de pesquisador e à sua trajetória intelectual, ficando fora dessa seleção as cartas cotidianas, de cunho estritamente pessoal. Tendo por fundamento essas cartas, é possível mapear intelectuais que auxiliaram Smith no 
decorrer das pesquisas e detectar os colaboradores do Sphan em diferentes regiões do Brasil. Por sua trajetória acadêmica, temáticas de pesquisa e vínculos institucionais, Smith tornou-se "uma das pessoas mais estimadas pelo órgão que no Brasil se ocupa da proteção e do estudo sistemático de nossos monumentos, o então Serviço e agora Diretoria do Patrimônio Histórico e Artístico Nacional". Pesquisas, consultas, fotografias, plantas, contatos, tudo foi facilitado a Smith pelo então diretor Rodrigo Melo Franco de Andrade, em uma "demonstração inequívoca de apreço, confiança e desprendido espírito de colaboração que honra a cultura brasileira."9

A comunicação entre Robert Smith e Rodrigo Melo Franco teve início antes mesmo da primeira viagem de Smith ao Brasil, em 1937; iniciou-se com comentários de Smith no Handbook Of Latin American Studies (HLAS) sobre o trabalho de Rodrigo no Sphan. ${ }^{10}$ No artigo "Robert Smith, diálogos e pesquisas no Brasil", Cecília Pereira" discute a interlocução de Smith com representantes do PHAN, principalmente Rodrigo Melo Franco de Andrade. $O$ enfoque da autora não foi discutir questões relacionadas à História da Arte, e sim perceber as trocas que possibilitaram suas pesquisas no país. Portanto, dialogando com a pesquisa de Cecília Pereira e ao mesmo tempo buscando ampliar o escopo, o presente artigo propõe uma análise das duas primeiras viagens de Smith ao Brasil e seus deslocamentos, impressões e trocas intelectuais, analisadas a partir dos arquivos de correspondências existentes no Iphan e na Fundação Calouste Gulbenkian.

Pessoalmente, Smith e Rodrigo conheceram-se em março de 1937 durante uma visita a sítios coloniais. Desse primeiro encontro em diante, Smith e Rodrigo estabeleceram relação de colaboração e amizade, documentada em cartas trocadas por durante mais de trinta anos. Dentre as inúmeras "gentilezas" realizadas por Melo Franco, Smith destacou:

Facilitou no Brasil as minhas viagens e pesquisas. Enviou-me no estrangeiro cópias de fotografias, livros, apontamentos. Publicou os meus estudos. Mandou circular as minhas exposições fotográficas, promoveu as minhas conferências. E sempre manteve a sua correspondência com uma regularidade encantadora, fornecendo informações, fazendo comentários, elogiando pequenas coisas minhas, prodigando sempre aquelas suas palavras de conforto e compreensão: "O Senhor não desanime... precisamos muito do senhor". ${ }^{12}$

Em um total de 192 correspondências que abarcam o período de 1945 a 1975, mais da metade foram trocadas entre Robert Smith e Rodrigo Melo Franco. Os intelectuais que aparecem nas correspondências, como, por exemplo, Augusto Silva Telles, Hélio Simões, Renato Soeiro, eram, na sua maioria, vinculados ao
9. Gonçalves (1976, p. 4).

10. Entretanto, a primeira carta que consta no arquivo do SPHAN é datada de $1^{\circ}$ de janeiro de 1945 , na qual Smith agradeceu a Rodrigo pelas indicações feitas durante a viagem a Pernambuco. Smith (1945).

11. Pereira (2014).

12. Ibid. 
13. Andrade (1946).

14. Smith (1937c).
Sphan e passavam pela intermediação de Rodrigo Melo Franco para assessorar Smith durante suas viagens pelo Brasil. Além das correspondências enviadas diretamente por Smith, consta nos arquivos cartas de Rodrigo Melo Franco aos colaboradores do Sphan nos diferentes estados brasileiros, geralmente solicitando e recebendo informações e pequenos relatórios dos trajetos de Smith e relacionadas a trâmites de documentação e fotografias a serem utilizadas em suas pesquisas.

O fluxo de correspondências entre Smith e intelectuais brasileiros a partir de 1945 foi muito intenso e estendeu-se até 1975, momento que extrapola o escopo desta pesquisa. Diante disso, realizei um levantamento geral das correspondências pesquisadas nos arquivos do Iphan e da Fundação Calouste Gulbenkian organizado por quadros e pelo gráfico a seguir. No arquivo do Iphan, foram encontradas um total de 192 correspondências datadas do ano de 1945 até 1975; já na Fundação Calouste Gulbenkian, 39 correspondências entre 1946 e 1975. Baseando-se nessa listagem, é possível mapear o fluxo de correspondências de cada ano e a rede de colaboração formada pela incidência dos nomes citados, além do levantamento das temáticas principais tratadas nas cartas.

Foram fotografadas dezenove correspondências datadas de 1945, da quais dez estão datilografadas em inglês. Os principais nomes citados naquele ano foram o de Alexander Marchand e Milton da Costa. Marchand visitou o Brasil por intermédio de Smith e Milton da Costa visitou os Estados Unidos recomendado por Rodrigo Melo Franco. A temática preponderante naquele ano foi justamente o intercâmbio desses intelectuais, seus objetivos de pesquisa e as possibilidades de intermediação tanto do Sphan como de Robert Smith nos Estados Unidos.

Referentes ao ano de 1946 foram encontradas dezenove cartas, sendo uma delas datilografada em inglês. Naquele ano, houve um grande fluxo de cartas enviadas por Rodrigo Melo Franco aos representantes do Sphan, solicitando serviços para Robert Smith. Dentre elas, cartas enviadas aos correspondentes André Carloni, do Espírito Santo, e uma correspondência enviada ao inspetor da Alfândega do Rio de Janeiro, na qual Rodrigo intercede pela liberação do equipamento fotográfico de Smith: "solicito vossas providências no sentido de ser liberado o seguinte material trazido dos Estados Unidos, em dois volumes, pelo professor Robert Chester Smith e destinado a esta repartição: uma máquina fotográfica brand, com o respectivo tripé e 60 filmes fotográficos". ${ }^{13}$

Antes, durante e após suas viagens ao Brasil, Smith enviava documentos e relatórios a Rodrigo Melo Franco. Da viagem de 1937, ofereceu uma série de fotografias realizadas nos diferentes estados por ele visitados, um "registro visual que fizemos neste país na salvaguarda de nossos próprios monumentos coloniais e do início do século XIX". ${ }^{14}$ Smith enviava previamente seus roteiros, e Rodrigo 
comunicava-se com os colaboradores nos diferentes estados brasileiros para que recebessem e acompanhassem Smith em suas pesquisas. Por sua vez, os colaboradores enviavam relatórios a Rodrigo, com detalhes da recepção e das atividades realizadas na companhia de Smith.

Caso o estado visitado não contasse com representantes do Sphan, Rodrigo estabelecia contato com interlocutores influentes do local, como aconteceu em São Luís do Maranhão, em carta enviada a Pedro Guimarães Pinto, na qual solicitou assistência a Smith e que "qualquer despesa feita com a finalidade de atender à minha solicitação, providenciarei para indenizá-la". ${ }^{15}$ Smith foi apresentado como

um dos mais doutos estudiosos da História de nossas artes plásticas, além do propagandista mais caloroso que esta repartição tem tido no estrangeiro de suas atividades. ${ }^{16}$

A mediação de Rodrigo para a abertura de um espaço de pesquisa para Smith foi fundamental, principalmente nos arquivos militares e religiosos, locais onde geralmente os pesquisadores encontraram dificuldades em acessar os materiais. Em 1947, solicitou ao pesquisador Kasys Vosylius - já contratado por ele em outras ocasiões - que realizasse uma busca do prospecto da cidade do Rio de Janeiro ${ }^{17}$ no arquivo Militar; porém, Vosylius sentiu-se intimidado e receoso diante dos oficiais do exército, necessitando de recomendação, ação que Rodrigo Melo Franco estaria impossibilitado de fazer por desconhecer os nomes dos policiais. ${ }^{18}$ Melo Franco investigou os nomes dos militares para que Kasys Vosylius pudesse prosseguir a pesquisa. ${ }^{19}$ Naquele mesmo ano, Smith passou por uma situação similar em Maragogipe, na Bahia. Enquanto pesquisava e transcrevia documentos na lgreja Matriz, foi interrogado por um subdelegado de polícia. Em carta, comunicou o ocorrido a Rodrigo:

\footnotetext{
Desejo dizer-the também que, se por acaso lesse um telegrama da Bahia publicado no Rio, dizendo que eu tinha estado preso em Maragogipe, quando copiava velhas inscrições na matriz, não o deveria levar a sério. Foi um exagero absurdo. Tratava-se meramente duma interrogaçãozinha feita por um subdelegado de polícia super zeloso, que evidentemente tem pouco contato com estrangeiros e muita curiosidade. ${ }^{20}$
}

Em Tiradentes, Minas Gerais, Smith relatou a seguinte situação: "tive o desgosto de ter as minhas fotografias embargadas pelo sacristão, cumprindo ordens do senhor vigário". ${ }^{21}$ A pesquisa em arquivos, conforme mencionado, foi um dos aspectos centrais
15. Andrade (1953).

16. Ibid.

17. Smith buscava o panorama/prospecto do Rio de Janeiro, encomendado pelo Conde de Bobadela. Seria um exemplar da iconografia colonial, considerada por Smith como uma das plantas mais importantes sobre a cidade, devido à perfeição de sua execução, à antiguidade de sua datação, pela documentação de edifícios, como a Igreja São Bento, São Bento dos Clérigos, São Francisco e Palácio dos Governadores. Considerou que seria impossível escrever sobre o Rio de Janeiro sem citar esse documento e não entendia por que José Mariano nunca citou tal fonte em seus estudos. Smith (1947b).

18. Andrade (1947).

19. Smith (1947d).

20. Id. (1947b)

21. Id. (1953). 
22. Filho de alemães (com pai fotógrafo), nascido na capital paulista, Herman Hugo Graeser, também conhecido como "Germano" Graeser, começou a colaborar com o Serviço do Patrimônio Histórico e Artístico Nacional (SPHAN) nos anos 1930, inicialmente sob as orientações de Mário de Andrade, quando o escritor era representante do órgão em São Paulo. A parceria com o SPHAN (depois DPHAN) estreitou-se e permaneceu até a morte de Graeser, em 1966, com 68 anos. Para mais informações, consultar: Costa (2016).

23. Martins, 1947. na metodologia de Smith; logo, a mediação de Rodrigo Melo Franco no acesso à documentação foi crucial para a produção dos artigos e livros posteriores às viagens.

Rodrigo Melo Franco e o Sphan ofereceram suporte para as pesquisas de Smith, arcando com despesas de reprodução de imagens, documentos e contratação de fotógrafos. As fotografias tiradas por Germano Graeser ${ }^{22}$ e Kazys Vossylius, de documentos e plantas do Rio de Janeiro, foram pagas pela instituição e enviadas por correios - por parte de Judith Martins, funcionária do Ministério da Educação e Saúde (MES) - para o Museu do Estado da Bahia a pedido de Smith. ${ }^{23}$ Com essa documentação, Smith teria todo o material necessário para a escrita de um livro cujo conteúdo passaria pela aprovação de Rodrigo - sobre a arquitetura colonial brasileira, cujo esboço se encontra no arquivo da Fundação Calouste Gulbenkian.

A cooperação entre Smith e "os amigos do patrimônio" foi duradoura e se consolidou através da troca de materiais fotográficos, referências bibliográficas, indicações para publicações em revistas, auxílio financeiro, indicações para pesquisas em arquivos e recomendações para intercâmbios de intelectuais.

\section{A VIAGEM DE 1937: UM MAPEAMENTO DA ARTE E ARQUITETURA COLONIAL BRASILEIRA}

Em 2 de abril de 1937, com uma bolsa de estudos da American Council of Learned Societies, Robert Chester Smith desembarcou no Rio de Janeiro. A viagem teve duração de quatro meses e, durante aqueles 120 dias, percorreu, de trem, avião, ônibus e a cavalo, diversas cidades brasileiras. A finalidade era entender as manifestações da arte colonial por intermédio da arquitetura, do mobiliário, das pinturas e dos arquivos visitados. No Quadro 1, estão listadas todas as cidades visitadas por Smith durante a viagem de 1937, o tempo de estadia, o representante do Sphan que o recebeu e os principais arquivos pesquisados. Todas as viagens realizadas de avião em 1937 foram feitas pela empresa Panair do Brasil S.A. As despesas áreas foram pagas com o auxílio de mil dólares concedido pela American Council of Learned Societies (ACLS) e com ajuda financeira do Sphan. 


\begin{tabular}{|c|c|c|c|c|}
\hline Estado & Cidades & Data & $\begin{array}{c}\text { Representante do } \\
\text { Iphan }\end{array}$ & Arquivos pesquisados \\
\hline Rio de janeiro & $\begin{array}{l}\text { Rio de Janeiro, } \\
\text { Niterói, Paquetá }\end{array}$ & $\begin{array}{l}2 / 04 / 1937 \text { a } \\
19 / 04 / 1937\end{array}$ & $\begin{array}{l}\text { Rodrigo Melo } \\
\text { Franco de Andra } \\
\text { Renato Soeiro }\end{array}$ & $\begin{array}{l}\text { - Arquivo do Exército, } \\
\text { Arquivo do Itamara } \\
\text { ty, Arquivo Nacional, } \\
\text { Biblioteca Nacional, } \\
\text { Real Gabinete Portu } \\
\text { guês de Leitura, Instituto } \\
\text { Histórico e Geográfico } \\
\text { do Brasil, Museu Histó- } \\
\text { rico Nacional, Galeria } \\
\text { de arte da Escola Na- } \\
\text { cional de Belas Artes; } \\
\text { Arquivo Militar do Mi- } \\
\text { nistério da Guerra }\end{array}$ \\
\hline Minas Gerais & $\begin{array}{l}\text { Barbacena, Belo } \\
\text { Horizonte, Cae- } \\
\text { té, Congonhas } \\
\text { do Campo, Juiz } \\
\text { de Fora, Maria- } \\
\text { na, Matozinhos, } \\
\text { Ouro Preto, Sa- } \\
\text { bará, Santa Lu- } \\
\text { zia, e São João } \\
\text { Del Rey, Santa } \\
\text { Bárbara, Catas } \\
\text { Altas, Santa Rita }\end{array}$ & $\begin{array}{l}19 / 04 / 1937 a \\
07 / 05 / 1937\end{array}$ & $\begin{array}{l}\text { Augusto de Lima } \\
\text { Júnior, Guy de } \\
\text { Holanda, Theo- } \\
\text { philo Féu de Car- } \\
\text { valho }\end{array}$ & $\begin{array}{l}\text { Arquivo Público Minei- } \\
\text { ro, Arquivo do Arce- } \\
\text { bispado de Mariana, } \\
\text { Delegacia Regional } \\
\text { do Sphan, Biblioteca } \\
\text { da Casa dos Contos, } \\
\text { Museu de Mariano } \\
\text { Procópio Ferreira Laje }\end{array}$ \\
\hline São Paulo & Santos & $\begin{array}{l}22 / 05 / 1937 a \\
24 / 05 / 1937\end{array}$ & Luís Saia & $\begin{array}{l}\text { - Museu Paulista, Mu } \\
\text { seu da Cúria, Museu } \\
\text { do lpiranga }\end{array}$ \\
\hline Espírito Santo & $\begin{array}{l}\text { Vitória, Aracruz, } \\
\text { Anchieta, Ara- } \\
\text { çatuba e Nova } \\
\text { Almeida }\end{array}$ & $\begin{array}{l}25 / 05 / 1937 a \\
26 / 05 / 1937\end{array}$ & André Carloni & $\begin{array}{l}\text { Museu de Arte Religio- } \\
\text { sa de Vitória }\end{array}$ \\
\hline Bahia & Salvador & $\begin{array}{l}26 / 05 / 1937 a \\
10 / 06 / 1937\end{array}$ & Hélio Simões & $\begin{array}{l}\text { - Inspetoria de Museus } \\
\text { e Monumentos do Esta- } \\
\text { do da Bahia, Instituto } \\
\text { Histórico e Geográ } \\
\text { fico da Bahia, Casa } \\
\text { da Torre de Garcia } \\
\text { D'Ávila, Universidade } \\
\text { Federal da Bahia, Ar- } \\
\text { quivo Militar da Bahia }\end{array}$ \\
\hline Sergipe & Aracaju & $\begin{array}{l}10 / 06 / 1937 a \\
10 / 06 / 1937\end{array}$ & - & - \\
\hline
\end{tabular}




\begin{tabular}{|c|c|c|c|c|}
\hline Estado & Cidades & Data & $\begin{array}{c}\text { Representante do } \\
\text { Iphan }\end{array}$ & Arquivos pesquisados \\
\hline Maranhão & São Luiz & $\begin{array}{l}26 / 06 / 1937 a \\
30 / 06 / 1937\end{array}$ & - & $\begin{array}{l}\text { Pesquisou casarões } \\
\text { do período colonial e } \\
\text { percebeu influências } \\
\text { italianas }\end{array}$ \\
\hline Pernambuco & Olinda, Recife & $\begin{array}{l}11 / 06 / 1937 a \\
26 / 06 / 1937\end{array}$ & $\begin{array}{l}\text { Ayrton de Carva- } \\
\text { lho }\end{array}$ & $\begin{array}{l}\text { Arquivo Municipal do } \\
\text { Estado de Pernambu- } \\
\text { co, Arquivo Municipal } \\
\text { de Olinda, Universi- } \\
\text { dade Federal de Per- } \\
\text { nambuco, Fundação } \\
\text { Joaquim Nabuco } \\
\text { - Delegacia Regional } \\
\text { do Sphan } \\
\text { - Instituto Histórico e } \\
\text { Geográfico de Per- } \\
\text { nambuco }\end{array}$ \\
\hline- & - & - & - & $\begin{array}{l}\text { - Mosteiro de São } \\
\text { Bento de Olinda, Insti- } \\
\text { tuto Arqueológico Per- } \\
\text { nambucano }\end{array}$ \\
\hline Pará & Belém & $\begin{array}{l}31 / 06 / 1937 a \\
05 / 07 / 1937\end{array}$ & Ernesto Cruz & $\begin{array}{l}\text { Arquivo Colonial de } \\
\text { Belém }\end{array}$ \\
\hline
\end{tabular}

Quadro 1 - Representantes do Sphan, cidades e arquivos visitados por Smith durante a viagem ao Brasil de 1937. Fonte: Melo (2018).

Smith realizou uma longa preparação antes de sua primeira viagem ao Brasil, começando com a investigação de documentos na Biblioteca de Harvard e, depois, nos arquivos portugueses, como anotações de viajantes e publicações do século XVIII, além de analisar obras produzidas entre os séculos XIX e XX. No relatório de viagem elaborado em 1937, para prestação de contas e atividades à American Council of Learned Societies (ACLS), afirmou que sua intenção era estudar a arquitetura colonial mineira, dando continuidade às suas pesquisas iniciadas em Harvard e em Portugal; além disso, ele se propôs a visitar "todos os outros locais de arquitetura colonial do Brasil". ${ }^{24}$ Frisou que sua viagem coincidiu com um momento de crescente interesse na cultura e nas instituições brasileiras em um período de aproximação entre Estados Unidos e Brasil, marcado pela visita do presidente Franklin Roosevelt, em 1936 e em 1943. A propósito dessa questão, Smith escreveu: 
Jamais nenhum estudioso americano com minha formação e experiência em português havia visitado o Brasil. Foi particularmente feliz a circunstância de esta viagem ter sido realizada logo depois da visita do nosso presidente ao Brasil. [...] naquele momento havia um grande interesse pela vida cultural e instituições brasileiras e a presença de vários investigadores e bolsistas. ${ }^{25}$

No trecho citado, o autor retomou o contexło da Política da Boa Vizinhança e a crescente aproximação com o Brasil. Essa aproximação e interesse pelo Brasil sobrevieram também por Portugal, país central na trajetória de Smith. Portanto, ele estava inserido em um projeto mais amplo, de cunho governamental com a aproximação de Brasil e Portugal, do varguismo e do salazarismo, em um momento de aproximação política e cultural entre os "países irmãos".

Os contatos estabelecidos no Rio de Janeiro foram inicialmente mediados pelo ministro das relações exteriores, Hélio Lobo, que concedeu a Smith cartas de recomendação endereçadas a Gustavo Barroso, do Museu Histórico do Rio de Janeiro, a Max Fleiuss, Secretário do Instituto Histórico e Geográfico Brasileiro (IHGB), e a Rodolpho Garcia, diretor da Biblioteca Nacional do Rio de Janeiro. Nesse primeiro contato, de cunho estritamente oficial e ainda se familiarizando com o meio intelectual carioca, Smith participou de alguns eventos na tentativa de ampliar sua rede de contatos. Esteve no encontro semanal do Instituto Brasil-Estados Unidos, presidido por Hélio Lobo, e nas celebrações do centenário de fundação do Real Gabinete Português de Leitura. Como instituição, o Gabinete Real de Leitura atuou na constituição e consolidação da cultura portuguesa no Brasil mediante seu acervo e do apoio à criação de outras instituições luso-brasileiras. Ainda que tenha sido o único representante estadunidense ${ }^{26}$ na comemoração, Smith, de certa forma, representava Portugal, em virtude de seu intercâmbio recente naquele país entre os anos de 1934 e 1936, considerado como uma "preparação" para a viagem ao Brasil, em 1937. Os contatos criados no Rio de Janeiro facilitaram o acesso de Smith aos arquivos e bibliotecas, além de possibilitar o registro de documentos escritos e imagens. Nas palavras de Smith, "I called upon all of these gentleman who received me with the greatest kindness, putting at my disposal all the resources of their several libraries, granting permission for me to photograph painting me with copies of their $\mathrm{OW}^{\prime \prime} .{ }^{27}$

Com base em fotografias de imagens da arquitetura colonial registradas no Rio de Janeiro e em Niterói, Smith elaborou um catálogo visual das igrejas oitocentistas e anexou nesses registros algumas construções modernistas. Nas ilhas de Paquetá e Bom Jesus, fez o registro fotográfico de plantas e folhagens tropicais, entendidas como lembranças das colônias de verão da Corte Portuguesa de Dom João VI (1 8081822). Em visita à Biblioteca Nacional e ao Museu Histórico do Rio de Janeiro, realizou um registro fotográfico de documentos, gravuras e aquarelas de monumentos de Minas Gerais, uma pesquisa documental das representações visuais de edificações
25. Id. (1937, p. 21).

26. O Gabinete Real de Leitura foi fundado em 14 de maio de 1837. Na data da cerimônia de comemoração do centenário da instituição, que ocorreu no teatro João Caetano, Smith havia retornado de sua viagem a Minas Gerais no dia 9 de maio de 1937.

27. Tradução: "Fui chamado por todos esses cavalheiros que me receberam com enorme bondade, colocando a minha disposição todos os recursos das diversas bibliotecas, concedendo permissão para fotografar pinturas e documentos confiados aos seus cuidados". (Smith, 1937b, p. 4). 
28. Não há como afirmar que esse fotógrafo seria o poeta, escritor e crítico judeu francês, influente no período surrealista e amigo de Picasso ou apenas um homônimo.

29. Smith (1937b, p. 3).

\section{Ibid.}

31. Ibid. (p. 9).

32. Smith (1953, p. 230).

33. Smith s/d apud Wood (2000, p. 40). coloniais mineiras, que, em breve, ele conheceria pessoalmente. Para os referidos registros, contou com a colaboração do fotógrafo Max Jacob, ${ }^{28}$ que tirou fotografias coloridas dos documentos e pinturas relacionados a Minas Gerais. ${ }^{29}$

Buscando fortalecer sua rede de colaboração, em 16 de abril de 1937, por intermédio de Augusto de Lima Júnior, visitou e conheceu os funcionários do Sphan, no Rio de Janeiro, inclusive o diretor Rodrigo Melo Franco, com quem já havia trocado correspondências, mas que ainda não conhecia pessoalmente. Em seguida, foi recebido pelo Ministro da Educação Gustavo Capanema, que indicou Guy de Holanda para acompanhá-lo a Minas Gerais. Assim como os modernistas viajaram a Minas Gerais em busca de monumentos e resquícios de um passado colonial, o mesmo fez Robert Smith. Após dezessete dias de sua chegada ao Rio de Janeiro, em 19 de abril de 1937, no trem das 18h30min, viajou para Minas Gerais. Foi recepcionado pelo representante do Sphan, Augusto de Lima Júnior, que o acompanhou nas visitas às cidades de Barbacena, Belo Horizonte, Congonhas do Campo, Juiz de Fora, Mariana, Ouro Preto, Sabará e São João Del Rey; essa visita teve duração de aproximadamente seis semanas. ${ }^{30}$

A intenção de Smith em Minas Gerais era visitar os principais sítios de arquitetura colonial, estudar esses monumentos detalhadamente, fotografar as principais características dos edifícios e estabelecer contato com os principais historiadores locais - estudiosos de arte, arquivistas e colecionadores. Além disso, seu intento era

fazer um catálogo das igrejas e capelas mais importantes, fotografar dentro e fora estudando o estilo de "forragem de madeira" (talha) dos interiores, olhar as esculturas ou pinturas de valor, observar o arranjo da sacristia, sempre o elemento mais importante nas arquiteturas das igrejas Portuguesas-Brasileiras. Por fim, desenhar as plantas das mais interessantes igrejas mineiras, além de realizar um estudo similar da arquitetura civil. ${ }^{31}$

Smith já havia pesquisado sobre arquitetura colonial mineira antes de realizar a viagem, pois pretendia publicar um artigo na revista The Art Bulletin. Seu plano inicial de trabalho era comparar a arquitetura mineira com as demais regiões do país, ou seja, Minas Gerais ocupava um lugar central nessa etapa de sua trajetória. O cenário montanhoso da região foi associado às construções da região do Minho e Trás-os-Montes, e ele afirmou que, no decorrer do século XVIII, Minas Gerais produziu "uma série de monumentos mostrando os sucessivos estágios de todo o desenvolvimento da arquitetura colonial no Brasil". ${ }^{32}$

Augusto de Lima Júnior - considerado por Smith "um dos mais brilhantes romancistas e historiadores de Minas Gerais" 33 - acompanhou-o durante toda a 
sua estadia e apresentou-o aos intelectuais da região que forneceram importantes informações para seu trabalho. Smith assim descreveu a importância desse encontro:

O contato mais benéfico para o meu trabalho, não só pela grande generosidade, para me apresentar a sua completa coleção de achados portugueses, mas me aconselhar nos meus planos de ação enquanto estiver em Minas Gerais e me arranjar uma série de valiosas recomendações. ${ }^{34}$

Em Ouro Preto, conheceu o engenheiro Epaminondas de Macedo, responsável pela restauração da arquitetura colonial de Minas Gerais, que o auxiliou nas pesquisas também em Belo Horizonte. $\bigcirc$ estado de conservação das construções mineiras havia se alterado quando comparado às primeiras viagens realizadas pelos modernistas, que apontaram um total abandono das construções. Em 1937, o Sphan começou a enviar representantes para os diferentes estados e a trabalhar na restauração das edificações. Smith considerou a arquitetura mineira do período colonial uma das mais conservadas de todas as regiões visitadas no país.

Em 22 de abril de 1937, a convite do Dr. Alberto Mansoni de Andrade, professor da Escola de Minas, Smith proferiu uma palestra no Clube do Automóvel de Ouro Preto, intitulada "Impressões Sobre Villa Rica", na qual argumentou sobre a "dependência" do estilo colonial da arquitetura de Ouro Preto em relação àquelas das províncias do norte de Portugal oitocentista. No dia seguinte, seguiu a cavalo até as capelas de Santa Anna, São João e São Sebastião, inacessíveis de automóvel por ficarem nas montanhas. Durante essa viagem, produziu fotografias de todas as construções coloniais da cidade; em suas próprias palavras: uma "inestimada aquisição documental da antiga Villa Rica". ${ }^{35}$

Em 27 de abril de 1937, partiu de trem para Belo Horizonte, onde conheceu o historiador e arquivista Theophilo Féu de Carvalho que, além de fornecer "documentos importantes", foi considerado por ele como "um dos mais eminentes investigadores-arquivistas e arqueólogos do Brasil". ${ }^{36}$

Em 2 de maio de 1937, visitou a cidade de Sabará e fotografou igrejas e casas oitocentistas, fez o mesmo nas cidades de Caeté, Morro Grande, Santa Luzia, Matozinhos e Congonhas do Campo. Nesta última cidade foi com a intenção de realizar estudos sobre os trabalhos do escultor Antônio Francisco Lisboa, o Aleijadinho (1730-18 14). Segundo Smith, Aleijadinho adquiriu grande familiaridade com o estilo do norte de Portugal e o exerceu com tamanha maestria que the atribuiu um cunho pessoal. Nos trabalhos iniciais do escultor, Smith percebeu "a força da tradição aparente" e uma grande aproximação com as igrejas portuguesas: 
37. Smith (1953, p. 230).

38. Como Robert Smith, Frank Tennebaum (Nova York), Henri Hauser (França), Percy Martin (Califórnia), Alcides Bezerra, Raja Gabaglia, Vilhena de Moraes, Wanderley Pinho, dentre outros. Os diretores eram Eremildo Viana, Carlos Cantão e Guy de Holanda, este último viajou para Minas Gerais na companhia de Robert Smith.

39. Smith citou os seguintes artigos de Féu de Carvalho: Reminiscências de Vila Rica... Casa das Audiências, Câmara e Cadeia. Revista do Arquivo Público Mineiro, v. 19, p. 269-344, 1921 e Ementário da História de Minas. Felipe dos Santos Freire na Sediação de Vila Rica, Belo Horizonte, s/d.
Essas igrejas são ultrapassadas pela maestria com a qual Aleijadinho - que se definia como um escultor ornamental - concebe e executava na suave pedra-sabão as pilastras ondulantes e os perfis agitados dos lenteis e as delicadas fitas e tarjas como formas de asas. Isto é especialmente verdade nos últimos portais, mais evoluídos em sua intrincada escultura e mais perfeitamente integrados no esquema geral. ${ }^{37}$

Em 7 de maio de 1937, visitou Barbacena, Luz e São João Del Rey. Em seguida, foi a Tiradentes, última cidade visitada em Minas Gerais antes de retornar ao Rio de Janeiro. Nas cidades mineiras, delineou sua metodologia de trabalho aplicada tanto nas igrejas quanto nas construções civis e militares. Primeiramente, realizava um catálogo geral das igrejas e capelas consideradas por ele mais importantes para seus estudos. Em seguida, fotografava as construções por dentro e por fora, sempre atento ao estilo da talha em madeira, esculturas, pinturas e estilo das sacristias na parte interior. Por fim, desenhava as plantas mais interessantes a fim de documentar as construções para escritos posteriores.

Das trocas intelectuais, pesquisa arquivística e do contato direto com as obras de arte e a arquitetura mineira, resultou o artigo "Minas Gerais no Desenvolvimento da Arquitetura Religiosa", primeiro trabalho publicado em português, no Boletim do Centro de Estudos Histórico do Rio de Janeiro, em 1938. O Boletim era vinculado ao Museu Nacional, contava com publicações trimestrais e com um amplo comitê de redação, reunindo intelectuais nacionais e estrangeiros. ${ }^{38}$ No artigo "Minas Gerais no Desenvolvimento da Arquitetura Religiosa" (1938), apesar de Smith ter realizado um amplo levantamento fotográfico das igrejas e construções mineiras, e de o artigo propor uma análise dos elementos materiais que compõem as construções, como os sinos, escadarias, torres, portadas e decoração das sacristias, ele não fez uso de imagens. $\bigcirc$ artigo abordou as igrejas mineiras com enfoque no século XVIII, período no qual o barroco se definiu com suas mais expressivas formas. $\bigcirc$ historiador considerou que esse era um tema trabalhado com "pouco rigor científico", com exceção de algumas produções de Féu de Carvalho, citado inúmeras vezes em seu artigo.${ }^{39} \mathrm{~A}$ partir desse comentário, Smith colocava seus estudos no mesmo diapasão de pesquisa do Sphan, que, conforme frisou Melo Franco de Andrade no primeiro número da Revista do Patrimônio em 1937, buscava maior rigor documental nas suas publicações. Além disso, o enfoque direcionado a Minas Gerais nesse primeiro momento da viagem dialogava com um movimento de "culto à cidade de Ouro Preto".

Findada a viagem a Minas Gerais, Smith seguiu em direção a São Paulo. Desde o primeiro contato pessoal com Rodrigo Melo Franco, o historiador conseguiu autorização para visitar e fotografar a galeria de arte da Escola de Belas Artes, que, naquele período, estava fechada para reformas. Além disso, Rodrigo ofereceu 
uma carta de recomendação destinada ao arquiteto e representante do Sphan, Luís Saia, que o recebeu em São Paulo. Na capital paulista, esteve por apenas um dia, mas visitou todas as igrejas da capital e percorreu os arredores da cidade em busca de casarões seiscentistas. Afirmou, porém, não ter encontrado "nada de importante para [...] pesquisa, tudo foi destruído na construção dessa cidade enorme". ${ }^{40}$ Conheceu o Museu Paulista e considerou seu acervo um "dos mais importantes e preciosos do país, embora muito sacrificado pelas condições prejudiciais de sua exposição". " No Museu da Cúria, visitado por indicação de Rodrigo Melo Franco, encontrou "uma valiosa coleção de obras reunidas". ${ }^{42}$

De São Paulo, Smith direcionou-se para a região "nordeste" do país. Geograficamente, delimitou a região pelos estados de Alagoas, Bahia, Ceará, Espírito Santo, Paraíba, Pernambuco e Sergipe, definida por duas tradições arquitetônicas bem demarcadas. A primeira tenderia à "imitação" do estilo barroco de igrejas rurais das províncias portuguesas e a outra, recorrente em Pernambuco e Bahia, "tomava emprestado" aspectos da decoração da arquitetura oficial da corte de Lisboa. A característica primordial da arquitetura do Nordeste estava centrada nos solares da Bahia, nos claustros das ordens religiosas, nas ricas sacristias dos templos metropolitanos e dos conventos. ${ }^{43}$

Das mais de trinta publicações de Smith sobre o Brasil, metade foi dedicada ao nordeste, principalmente às cidades do Recife e Salvador. ${ }^{44}$ A primeira cidade visitada na "região nordeste" foi Vitória, Espírito Santo. Smith aterrissou em Vitória em 25 de maio de 1937. Ficou um dia na cidade e visitou o Convento de Nossa Senhora da Penha, fundado no século XVI, construção que o interessou pela escadaria de gesso datada de 1774 e do interior esculpido em Jacarandá. Em 1943, o Sphan principiou um trabalho de restauração no monumento em razão de seu tombamento como patrimônio histórico e artístico nacional. No mesmo ano do tombamento, a construção figurou o catálogo da exposição "Brazil Builds: architecture new and old 1652-1942", realizada no MoMA. ${ }^{45}$ A visita de Robert Smith foi anterior ao tombamento de 1943; entretanto, em 1946, em sua segunda viagem ao Brasil, visitou o local novamente. Possivelmente, a visita se relaciona com todo esse contexto, em virtude do contato mantido pelo historiador com o arquiteto Philip Goodwin e o G. E. Kidder Smith, autor e fotógrafo de Brazil Builds, respectivamente.

Continuando o percurso pela região nordeste, Smith direcionou-se para Salvador, onde esteve por duas semanas a fotografar igrejas, conventos e realizar pesquisas no Instituto Histórico da Bahia. Em 3 de junho de 1937, jantou com Donald Pierson, "que viveu em Salvador pelos últimos dois anos estudando costumes africanos preservados pelos negros baianos, sob os auspícios do Conselho de Psicologia da Universidade de Chicago". ${ }^{46}$ Pierson forneceu uma "série de
40. Smith (1937b, p. 7).

41. Id. (1947a p. 10).

42. Ibid. (loc. cit.).

43. Id. (1938, p. 34).

44. As obras de Smith publicadas sobre a região nordeste são: $O$ caráter $d a A r$ quitetura Colonial do Nordeste (1940c), As Paisagens Brasileiras de Franz Post (1939), Os Velhos Templos do Recife (1944), Documentos Baianos (1945); Santo Antônio do Recife (1946); Algumas Vistas da Babia (1948); A Praia da Madeira no Recife. Uma Contribuição para a História Econômica do Brasil (1949); Arquitetura Colonial Baiana: alguns aspectos de sua bistória (1951); Uma Cadeia, Uma Capela e duas Casas. Desenhos de Arquitetura Colonial Brasileira (1951a); O Prospecto de Caetano: Um Panorama setecentista do Recife (1954); Arquitetura Colonial: Artes na Babia Parte I (1955); O Mercado do Peixe na Vila do Recife (1979); Aspectos da Arquitetura da Basílica da Conceição da Praia: Bicentenário de um Documento Baiano (1985).

45. Rocha (2014, p. 15). 46. Smith (1937a, p. 56). 
informações" sobre cultos de adoração africanos e sua influência nas igrejas brasileiras a Robert Smith, que citou algumas informações na publicação sobre arte brasileira no Manual Bibliográfico de Estudos Brasileiros (1998), mas não se aprofundou em nenhum aspecto referente a tais questões.

Na Bahia, visitou as cidades de Amaralina, Brotas e do Recôncavo: Vila de São Francisco, Santa Amaro da Purificação, São Félix e Cachoeira, locais onde localizou diversos exemplares de casas da aristocracia baiana. Na arquitetura religiosa, percebeu que as igrejas baianas se diferenciavam das mineiras pelo uso de pedras importadas de Lisboa e pela aplicação de azulejos portugueses nos interiores. Smith catalogou três tipos de azulejos: aqueles com padrões geométricos do século XVII, pintados em azul, amarelo e branco; os azulejos do século XVIII em azul e branco com cenas contemporâneas, episódios das escrituras ou vida dos santos, alegorias e desenhos florais; e os do final do século XVIII, pintados em azul, branco, amarelo e rosa em padrões neoclássicos. Já as fachadas contavam com três a cinco portas frontais, diferente da portada única das igrejas mineiras. Suas torres eram mais monumentais e apresentavam arcos na parte interior das fachadas, característica da renovação estilística ocorrida em Portugal durante a Contrarreforma, a partir de 1545. Tais características foram percebidas nas igrejas da Sé, Santa Casa de Misericórdia, São Francisco, São José do Ribamar, Convento do Carmo; Santo Amaro e Matriz da Purificação.

Após a Bahia, esteve no estado de Pernambuco por duas semanas. Sua primeira preocupação foi estudar a influência holandesa na arquitetura de Recife e Olinda. Baseando-se na visualidade das construções e nas pesquisas documentais realizadas nos arquivos do Instituto Arqueológico Pernambucano e nos desenhos do pintor holandês Frans Post. Nas igrejas pernambucanas, verificou que as torres eram extremamente altas, com muitos ornamentos nas extremidades e ficou surpreso com a conservação das mobílias em jacarandá. Outra característica percebida por ele nas sacristias, de Pernambuco, Sergipe e Paraíba, foi a presença do lavatório em um nicho separado, geralmente abobadado e iluminado por duas pequenas janelas laterais. Tais características, segundo o pesquisador, contribuíram para a formação de um estilo particular da região. Na arquitetura civil, percebeu a influência holandesa nas casas de campo e engenho e nas residências urbanas, sobretudo nos estilos das varandas esculpidas em madeira, um diferencial relativamente às demais regiões do país, onde foram predominantes as casas de portas e janelas.

De Recife, seguiu, em 26 de junho de 1937, para São Luiz do Maranhão, onde permaneceu por cinco dias. Considerou São Luís uma cidade "distinta pela beleza de Portugal do século XVIII, com casas de grandes proporç̃ẽes. Construções imponentes, nenhuma outra que tenha preservado tantas das varandas originais de 
ferro "delicado" ao estilo Luiz XV", 47 características incomuns em outras cidades brasileiras. Encontrou, naquela cidade, traços da arquitetura italiana, estilo introduzido em Lisboa na década de 1740, pelo arquiteto de Mafra, João Frederico Ludovice, tema central de sua tese de doutorado defendida em 1936. São Luiz, segundo Smith, era "um dos locais mais importantes para estudar arquitetura colonial no Brasil, mas que até agora permanece bastante desconhecida". 48 No artigo "São Luíz do Maranhão" (1938), originalmente publicado na revista The Panamerican Traveler, Smith traçou um panorama histórico da cidade, desde o período da chegada dos portugueses ao Brasil, passando pelas diferentes tentativas de povoamento da região. Nesse artigo, utilizou duas fotografias coloridas de sobrados típicos de São Luís do Maranhão.

De São Luiz do Maranhão, seguiu para Belém do Pará, onde esteve por quatro dias e foi recebido por Ernesto Cruz. Na cidade, fotografou as famosas igrejas jesuítas no estilo "contrarreforma", como a Catedral de São Alexandre, do Carmo, Nossa Senhora das Mercês e São João Batista. Smith considerou o estilo das construções de Belém um "estilo de fronteira", visto que as construções encontradas no Amazonas, Santarém e nas ruínas das missões jesuíticas do Rio Grande do Sul seguiam os mesmos padrões. Já na arquitetura civil, localizou pequenas casas do século XVIII, com portas e janelas e gesso ornamental. Um estilo de casa predominante da burguesia urbana, recorrente, na opinião de Smith, em todas as regiões do país. Tal constatação foi utilizada pelo historiador para embasar sua tese sobre a "imitação universal da arquitetura portuguesa durante o período colonial, principalmente o estilo do norte de Portugal durante a primeira metade do século XVIII". ${ }^{49}$ No Arquivo Colonial de Belém, encontrou uma série de documentos e desenhos do século XVII referentes à Alfândega da Bahia e a outras construções brasileiras. Deixou Belém em 5 de julho, para Miami; antes, parou em Bahamas e Antilhas, buscando estudar a arquitetura colonial das "ilhas das índias ocidentais". 50

Ao finalizar a primeira viagem ao Brasil, Smith afirmou que, como pesquisador da American Council of Learned Societies (ACLS), realizou o que havia sido proposto pela instituição no decorrer de sua viagem: "uma investigação científica inédita sobre a arquitetura colonial a ser feita no Brasil". Ele retornou com uma coleção de aproximadamente 1500 fotografias que "cobriam quase todos os aspectos da arquitetura brasileira, e muitos outros a respeito da vida dos brasileiros". ${ }^{51}$ O segundo objetivo proposto pela ACLS foi que Smith estabelecesse redes de contato com intelectuais brasileiros, desde trocas de materiais e informações sobre a sua área de interesse até a organização de palestras e eventos. Para estabelecer tais contatos, Smith considerou que seus conhecimentos em português e suas investigações na Universidade de Coimbra foram imprescindíveis, além de ressaltar o seguinte: "minha viagem foi de extrema 
52. Ibid. (loc. cit.).

53. Foram eles: Minas Gerais no Desenvolvimento da Arquitetura Religiosa Colonial (1937), O Caráter da Arquitetura Colonial do Nordeste (1938), The Colonial Churches of Brazil (1938), The Colonial Architecture of Minas Gerais (1939), São Luiz do Maranhão (1938), As Paisagens Brasileiras de Frans Post (1938), Três Paisagens Brasileiras de Frans Post (1939), Alguns Desenhos de Arquitetura Existentes no Arquivo Ultramarino Português (1940), o Códice de Frei Cristóvão de Lisboa (1941) e Documentos Baianos (1945). importância para meu conhecimento, nenhum estudioso americano com essa formação e experiência em português jamais havia visitado o Brasil antes". 52

Como resultado dessa primeira viagem, Smith publicou sete artigos com enfoque nas principais cidades percorridas. ${ }^{53}$ Os artigos transitaram principalmente entre arquitetura, urbanismo e iconografia, e evidenciam o intenso trabalho de campo realizado pelo pesquisador, tanto na observação das edificações in loco quanto na pesquisa arquivística e no levantamento bibliográfico.

O mote dessa primeira viagem foi a catalogação e mapeamento da arquitetura do período colonial, e suas análises transitaram entre arquitetura religiosa, civil, elementos decorativos internos e externos. A partir das conexões realizadas por Smith e das comparações entre os estilos, nota-se a defesa da continuidade da arquitetura portuguesa no traçado das construções brasileiras, linhas de continuidade que ele defendeu especialmente na arquitetura e no urbanismo.

Robert Smith faz uma leitura do período colonial em um momento de emergência do modernismo no Brasil, período em que havia uma busca por rupturas e, ao mesmo tempo, uma procura pela tradição. Smith direcionou seu olhar para o passado colonial sob a perspectiva da continuidade, ao olhar para a arquitetura com base naquilo que aproxima Portugal e Brasil. Uma aproximação que adquire contornos políticos a partir de 1930. Ou seja, Smith lança um olhar para o passado colonial com a precisão historiográfica de pensar Portugal e Brasil como um só, quer dizer, no período colonial, não havia o Brasil como nação, este era continuidade, ou melhor, parte da metrópole, de um corpo político e também cultural.

Certamente, as adequações materiais, a criatividade estética e a inventividade permearam no caso da arquitetura, não apenas as matérias chamadas "conteúdo" após o idealismo alemão e o hegelianismo, as matérias das construções, as alegorias ou os materiais mais adequados e presentes no lugar, como o barro e a pedra sabão, em Minas Gerais, e o granito, no Rio de Janeiro. Consequentemente, Smith trata ao mesmo tempo de herança, ao falar do sentido de patrimonialização desses monumentos no instante em que realiza suas pesquisas, mas de uma presença mesma, material, de todos os condicionamentos portugueses na arquitetura do período colonial. Na seção seguinte, será abordada a viagem de 1946, passados quase dez anos desde a primeira viagem de Smith ao Brasil. 
A VIAGEM DE 1946: EM BUSCA DE REGISTROS ICONOGRÁFICOS

Passados dez anos de seu primeiro contato com o país, Robert Smith retornou ao Brasil em 1946, com apoio da Fundação Guggenheim. $\bigcirc$ ano de 1946, pós-Segunda Guerra Mundial, marcava o fim do Estado Novo e a inserção de um regime democrático com o governo de Eurico Gaspar Dutra. Nessa segunda visita, as redes de colaboradores do antigo Sphan, que, em 1946, passou a ser denominada Diretoria do Patrimônio Histórico e Artístico Nacional (Dphan), ${ }^{54}$ estavam consolidadas nos diferentes estados.

\footnotetext{
Os estudos latino-americanos, especificamente para o campo do patrimônio, arquitetura e arte do período colonial, ganhavam maiores projeções. Se em 1937 acontecia uma (re) descoberta do colonial por parte dos brasileiros que viajavam pelo interior do país em busca de vestígios e testemunhos do passado colonial, em 1947, grande parte das construções já havia sido catalogada, arquivos explorados e estudos realizados. Passados dez anos, o historiador atribui algumas mudanças ocorridas em seu campo de pesquisa à ałuação dos governos do Brasil e Portugal: Afortunadamente, desde 1937, os governos de ambos os países têm ajudado incessantemente o historiador da arte financiando campanhas de pesquisa documental. Em Portugal, a Academia Nacional de Belas Artes após cuidadosos estudos dos melhores métodos usados em outros países, fazendo um catálogo exaustivo dos monumentos locais, com cuidadosa documentação. Enquanto isso, o Brasil, o Sphan e o Ministério da Educação e Saúde estão conduzindo uma campanha intensiva no Rio de Janeiro e em Minas Gerais, Catalogando e documentado os monumentos coloniais. ${ }^{55}$
}

Ao justificar a relevância de seu regresso ao Brasil em 1946 à Fundação Guggenheim, insistiu novamente na importância de o historiador da arte formar seu próprio acervo imagético. Segundo ele, sem essas imagens, o trabalho produzido seria de pouco valor, pois não "comprovariam" as conclusões das investigações. Nos Estados Unidos e Europa, Smith teve contato com grandes coleções de fotografias disponíveis aos pesquisadores. Já no Brasil, encontrou dificuldades em acessar as coleções e encomendar fotografias. Nessa segunda viagem, trouxe duas câmeras Brand $4 \times 5$ polegadas para tirar fotos coloridas, e uma câmera Leica para capturar detalhes em preto e branco. Os seguintes locais foram registrados: Jardins projetados por Roberto Burle-Marx; prédios modernistas no Rio Janeiro, São Paulo e Belo Horizonte; esculturas policromadas, mobiliário e pinturas do Museu do Estado da Bahia; festivais populares na Bahia; prataria e imagens da lgreja do Espírito Santo; arquitetura militar do período colonial; pinturas de Lasar Segall; esculturas de Aleijadinho e, em particular, as estátuas dos profetas em Congonhas do Campo.
54. A segunda modificação na denominação do atual Instituto do Patrimônio Histórico e Artístico Nacional (IPHAN) ocorreu em 1946. Por meio do Decreto-lei $\mathrm{n}^{\circ}$. 8.534, de 2 de janeiro, o SPHAN, criado em 1937 pela Lei $\mathrm{n}^{\circ} .378$, de 13 de janeiro, foi transformado em Diretoria do Patrimônio Histórico e Artístico Nacional (DPHAN), mantendo a subordinação ao Ministério da Educação e Saúde (MES) - situação que perdurou até 1953, quando foi criado o Ministério da Saúde, e o MES passou a ser denominado Ministério da Educação e Cultura (MEC).

55. Smith (1949, p. 75-76). 
56. Na Fundação Hispânica Smith atuou como Diretor-Assistente entre 1939 e 1943 e realizou atividades como Chefe-Assistente da seção de gravuras e fotografias, foi encarregado da organização das exposições temporárias, atuou como curador e auxiliou nos projetos para preservação e restauração documental (Neistein, 2000, p. 183).A atuação de Smith na Fundação Hispânica foi importante para a consolidação de uma linha de pesquisa e integração a um movimento inicial nas universidades americanas para o estudo da arte e cultura luso-brasileira e latino-americana mediante o estabelecimento de centros de investigação e divulgação cultural por meio da permuta de materiais e de documentos.

57. Smith (1947a).

58. Ibid.

59. Tradução: Nos centros provincianos, onde quer que o DPHAN mantenha oficiais, representantes locais continuaram os amáveis serviços do diretor nacional. Automóveis foram colocados à disposição deste beneficiário para me habilitar a visitar lugares de difícil acesso. Nessas incursões, representantes me acompanharam para orientar os estudos e me explicar o excelente trabalho de preservação conduzidos pelo DPHAN em muitos desses lugares. Dessa maneira, recebi valorosas instruções de campo, que me pouparam consideráveis gastos nesta viagem. Smith (1947a, p. 2).
Com o subsídio da Embaixada Brasileira em Washington, trouxe filmes suficientes para produzir cerca de quinhentas fotografias de interiores e exteriores de prédios coloniais, além de esculturas e pinturas contemporâneas. Smith cedeu à Biblioteca do Congresso o direito de reproduzir as fotografias para fazerem parte da coleção do Arquivo de Cultura Hispânica, ${ }^{56}$ da divisão de Impressos e Fotografias, seção organizada por ele e que, naquele período, representava "a maior coleção em transparências coloridas de arte da América Latina nos Estados Unidos". ${ }^{57}$ A viagem de Smith foi facilitada mais uma vez pela Dphan, especialmente pela mediação de Rodrigo Melo Franco de Andrade que, de acordo com Smith,

fez-se disponível para conferências diárias, introduzindo a colegas estratégicos. Obtive, assim, acesso a arquivos especiais e estabelecimentos religiosos, fotografias de mobiliário e desenhos de prédios coloniais. ${ }^{58}$

Smith contou também com o apoio da instituição, que disponibilizou automóveis para sua locomoção a lugares de difíicl acesso e os representantes para acompanhálo nas visitas de campo, como descreveu no relatório produzido em 1947:

In the provincial centers, wherever Dphan maintains offices, local representatives continued the kind services of the national director. Automobiles were placed at the disposal of the recipient to enable him to visit sites not easily available. On these excursion representatives accompanied him to orient his studies and to explain to him the excellent work of preservation being carried on or already completed by Dphan at many of these sites. In this way the recipient received invaluable instruction in the field and was apared considerable expense in traveling. ${ }^{59}$

Smith estudou e fotografou a arquitetura do Rio de Janeiro, São Paulo, Bahia, Espírito Santo, Minas Gerais, Pernambuco e Pará. Seguiu praticamente o mesmo roteiro da primeira viagem, como é possível observar no Quadro 2. No entanto, o enfoque dessa visita incidiu principalmente nas fontes iconográficas, no levantamento e registro de imagens relacionadas à arte e arquitetura colonial e também moderna. Pesquisou em arquivos públicos e privados, como a Biblioteca Nacional, Biblioteca do Itamaraty, Arquivo Militar do Rio de Janeiro, Institutos Históricos e Geográficos, arquivos das prefeituras locais e arquivos das irmandades em busca de mapas, plantas, desenhos, gravuras e textos antigos. 


\begin{tabular}{|c|c|c|c|}
\hline Estado & Cidades & Data & Representante do Iphan \\
\hline Rio de janeiro & Cabo Frio, Petrópolis & $\begin{array}{l}25 / 07 / 1946 a \\
16 / 09 / 1946\end{array}$ & $\begin{array}{l}\text { Rodrigo Melo Franco de } \\
\text { Andrade e Renato Soeiro }\end{array}$ \\
\hline São Paulo & \begin{tabular}{|l|} 
Itanhaém, São Roque, Santo \\
Antônio, São Miguel e Embu.
\end{tabular} & $\begin{array}{l}16 / 09 / 1946 \text { a } \\
01 / 10 / 1946\end{array}$ & Luís Saia \\
\hline Minas Gerais & $\begin{array}{l}\text { Barbacena, Belo Horizonte, } \\
\text { Caeté, Congonhas do Campo, } \\
\text { Juiz de Fora, Mariana, Matozi- } \\
\text { nhos, Ouro Preto, Sabará, San- } \\
\text { ta Luzia, e São João Del Rey, } \\
\text { Santa Bárbara, Catas Altas, } \\
\text { Santa Rita Durão, Itatiaia. }\end{array}$ & $\begin{array}{l}01 / 10 / 1946 a \\
06 / 11 / 1946\end{array}$ & $\begin{array}{l}\text { Salomão Vasconcelos, } \\
\text { Sylvio de Vasconcellos. }\end{array}$ \\
\hline Espírito Santo & $\begin{array}{l}\text { Vitória, Aracruz, Anchieta, Ara- } \\
\text { çatuba e Nova Almeida }\end{array}$ & $\begin{array}{l}01 / 12 / 1946 \text { a } \\
08 / 12 / 1946\end{array}$ & André Carloni \\
\hline Bahia & Salvador & $\begin{array}{l}08 / 12 / 1946 a \\
02 / 03 / 1947\end{array}$ & $\begin{array}{l}\text { Hélio Simões José Valla- } \\
\text { dares }\end{array}$ \\
\hline Sergipe & Aracaju & $\begin{array}{l}10 / 06 / 1947 a \\
10 / 06 / 1947\end{array}$ & \\
\hline Maranhão & São Luiz & $\begin{array}{l}26 / 06 / 1947 a \\
30 / 06 / 1947\end{array}$ & - \\
\hline Pernambuco & Olinda, Recife & $\begin{array}{l}02 / 03 / 1947 a \\
11 / 04 / 1947\end{array}$ & $\begin{array}{l}\text { Edson Mota e Ayrton de } \\
\text { Carvalho }\end{array}$ \\
\hline Pará & Belém & $\begin{array}{l}11 / 04 / 1947 a \\
16 / 04 / 1947\end{array}$ & Clemente Cruz \\
\hline
\end{tabular}

Quadro 2 - Representantes do Sphan, cidades e arquivos visitados por Smith durante a viagem ao Brasil de 1946. Fonte: Melo (2018).

O regresso de Smith ao Brasil foi noticiado por diversos periódicos da época, assim como os roteiros e trajetos percorridos por ele. Seu regresso ao país foi considerado pela revista llustração Brasileira ${ }^{60}$ como um esforço empregado no sentido de aproximar "os povos do norte e do sul do continente". Segundo a própria revista, "Robert C. Smith resolveu passar um ano entre nós. Entusiasta das nossas coisas, Mr. Smith, há longos anos, não obstante sua mocidade se dedica a um interessante, mas exaustivo trabalho de aproximação cultural entre o seu país e o Brasil". ${ }^{61}$

Smith desembarcou no Rio de Janeiro em 25 de julho de 1946 e permaneceu na cidade até 16 de setembro. Visitou a cidade de Niterói, Campos, Cabo Frio e Petrópolis e fotografou monumentos da cidade. Especial atenção foi direcionada à coleção de fotografias do Dphan, na qual transcreveu cerca de trinta documentos referentes a construtores do período colonial. No Arquivo Militar do Ministério da Guerra, encontrou uma coleção de 35 desenhos de aquarela do 
62. Smith (1947, p. 2)

63. Ibid. (p. 9).

64. A mesma palestra foi apresentada novamente em 23 de outubro, na Escola de Minas, em Ouro Preto; em 4 de novembro, na Escola de Arquitetura da Universidade de Minas Gerais, em Belo Horizonte; no Instituto Nacional de Arquitetos, no Rio de Janeiro, em 21 de novembro; no Instituto Geográfico Histórico da Bahia, em Salvador, em 11 de dezembro; e em 10 de abril de 1947, na Escola de Belas Artes, Universidade do Recife, em 27 de dezembro 1946.

65. Smith (1947a). século XVIII, que representavam inúmeras construções do período, material "estudado pela primeira vez desde que foram acondicionados e recebidos".62

Seguindo uma orientação de pesquisa pautada nas fontes iconográfica, fotografou a grande coleção de desenhos e gravuras da Biblioteca Nacional e do Ministério das Relações Exteriores. As fontes iconográficas encontradas na Biblioteca Nacional eram diversas, tanto no tipo de material utilizado, nas técnicas e nas diferentes proveniências. Smith mapeou desenhos barrocos advindos da Itália, França e Portugal, além de desenhos, mapas e aquarelas do início do século XIX das regiões da Bahia, Rio de Janeiro, Minas Gerais e Espírito Santo. A maioria dos materiais agrupados durante a viagem serviu como fonte para a construção de artigos que ele publicaria em diferentes revistas após o fim de sua temporada no Brasil. Entre o material inédito fotografado, posteriormente doado à Fundação Hispânica para compor o acervo sobre América Latina, havia

desenhos europeus barrocos oriundos da ltália, França e Portugal, manuscritos pictóricos da Bahia, Rio de Janeiro, Mariana em Minas Gerais e Linhares no Espírito Santo; mapas e aquarelas do Caminhos dos Itinerantes, um atlas do começo do século XIX de rotas terrestres ao longo da costa; aquarelas da cidade de Belém e sua flora e fauna do Rio Negro, feitas por Freire e Codina para o manuscrito Viagem Filosófica de Alexandre Rodrigues Ferreira de 1780; desenhos em caneta do século XVIII por Schwebel das missões Amazônicas; o inédito segundo álbum da Carta Soteropolitana compilada por Luiz dos Santos Wilhens em 1801; desenhos originais do século XVI de construções portuguesas e em Angola; uma coleção brasileira do século XIX que incluía desenhos de Moreau, Debret e Rugendas e muitas outras aquarelas de paisagens do Rio de Janeiro. ${ }^{63}$

Ainda no Rio de Janeiro, Smith proferiu uma palestra sobre a arquitetura de Thomas Jefferson para o Instituto Brasileiro de História da Arte. ${ }^{64} \mathrm{Em}$ seguida, direcionou-se para São Paulo e, se na primeira viagem afirmou não ter encontrado "nada de importante para sua pesquisa", ficando apenas um dia na capital e quatro dias percorrendo o estado, nessa segunda viagem, esteve por quinze dias, entre 16 de setembro e $1^{\circ}$ de outubro de 1946.

Trabalhou no Arquivo da Cúria Metropolitana e em desenhos arquitetônicos do Museu do Ipiranga. Visitou Santos, Itanhaém, São Roque, Santo Antônio, São Miguel e Embu. Hospedou-se na casa do pintor Lasar Segall, onde fotografou inúmeras obras do pintor além de escrever uma resenha crítica sobre o livro Mangue, de Lasar Segall, publicado em 1941, inaugurando assim seu contato mais próximo com artistas modernistas e no registro de suas obras. ${ }^{65}$

Sobre os contatos estabelecidos por Smith, no Rio de Janeiro, Rodrigo Melo Franco lamentou ter se esquecido de entregar a Smith uma carta de recomendação ao 
amigo Sérgio Buarque de Holanda, então diretor do Museu Paulista, no lpiranga. Mas salientou que "ele por certo já o conhece muito de nome e o aprecia devidamente, não havendo, assim, necessidade de recomendá-lo ao seu acolhimento cordial" .66

De São Paulo, Smith seguiu para Minas Gerais, onde foi recebido pelo representante do Dphan, Salomão Vasconcelos. ${ }^{67}$ Após realizar pesquisa no Arquivo Público Mineiro de Belo Horizonte, visitou as seguintes cidades: Sabará, Caeté, Santa Luzia, São João do Morro Grande, Santa Bárbara, Catas Altas, Santa Rita Durão, Itatiaia, Mariana, São Caetano, Conselheiro Lafaiete, Congonhas do Campo e Ouro Preto. ${ }^{68}$ Smith chegou a Ouro Preto em 11 de outubro de 1946; segundo ele, em "uma boa época", devido aos inúmeros eventos que ocorriam na cidade, como a reunião dos graduados da Escola de Minas, o baile e o Congresso de Geologia. ${ }^{69}$

Passados quase dez anos desde o primeiro contato com as cidades históricas brasileiras, relatou que foi possivvel perceber alterações significativas da atuação do Dphan na preservação dos centros históricos, principalmente em Ouro Preto. A mudança foi notada não nos grandes monumentos ou museus, mas nos detalhes, como nas cores aplicadas nas pinturas das fachadas, uma prática que, na sua concepção, deveria ser também adotada em Portugal. As fachadas de Ouro Preto e suas cores foram capturadas pelo olhar de Smith com sua câmera e filme colorido, percursos que o fizeram lembrar de sua primeira visita à cidade:

No chafariz de Antônio Dias vi a mesma mula bebendo água, um pouco além, apareceu a idêntica menina que me pediu para tirar um retrato dela, e quando ao fim do dia fiz a clássica subida da ladeira de São chico, descobri o mesmo deslumbrante panorama da Vila Rica inteira. ${ }^{70}$

Smith ficou hospedado na Casa da Baronesa de Camargo, residência mantida para "uso da equipe do Dphan", local onde se sentiu confortavelmente instalado e interessado pelo mobiliário colonial utilizado no interior da casa:

Estou otimamente instalado nesta casa da Baronesa gozando da minha cama colonial e do pessoal todo. D. Maria e Dr. Vasconcellos me têm prestado atenção generosíssima, de maneira que já enxergue com pesar a necessidade de sair daqui a dez dias. Vou gostar deste período como de umas férias no céu. E ficarei eternamente grato ao senhor de me ter proporcionado este imenso privilégio de passar uma temporada nesta cidade, hospedado em uma grande casa no verdadeiro coração dela. ${ }^{71}$ 
Robert Smith tratou a casa tombada da Baronesa como sendo de Rodrigo Melo Franco, apesar de o imóvel ter sido doado para o Dphan, em 1941, por Antônio Teixeira de Sousa Magalhães. Nota-se a pessoalidade na questão dos tombamentos, ainda incipiente para as residências. A mais antiga doação de imóveis para tombamento foi uma casa onde funciona a atual sede do Museu da Inconfidência em Ouro Preto, realizada em 1939. Posteriormente, outros imóveis foram doados, como o Sítio Santo Antônio, em São Roque, por Mário de Andrade, em 1944, e o Sítio Padre Inácio, no município de Cotia, por Rivadavia Mendonça, em 1945.

Smith percorreu diversas fazendas da região e, com a ajuda de Sylvio de Vasconcellos, representante regional do Dphan, produziu um apanhado de todas as plantas das construções a pedido de Rodrigo Melo Franco, além de um levantamento fotográfico e documental de monumentos e construções. Reencontrou o arquiteto Alberto Mazoni Andrade, que, relembrando a palestra que fizera em 1937, convidou Smith para proferir uma conferência na Sociedade Histórica de Ouro Preto.

Smith auxiliou o cônego de Ouro Preto a descobrir a autoria de imagens "presepiais" de São Francisco, assim como retratos reais existentes nos museus foram também identificados por ele. ${ }^{72}$ Para a descoberta de autoria, utilizou o Método Fogg, desenvolvido entre os professores e os pesquisadores do Departamento de Belas Artes de Harvard, onde se situa o Museu de Arte Fogg. O método propôs uma atenção meticulosa e investigativa aos detalhes que envolviam a obra de arte e sua atenção direcionada aos próprios objetos. $\bigcirc$ investigador deveria desenvolver capacidades de perito ao conseguir reconhecer a autenticidade, a autoria e a datação de obras não documentadas mediante comparações estilísticas.

Smith empregou o Método Fogg em diversos trabalhos, principalmente na investigação da talha portuguesa, em esculturas do barroco brasileiro e, em menor grau, nas pinturas dos ex-votos. Na arquitetura, o método não foi considerado confiável, pois a divisão de tarefas na execução da obra dificulta a atribuição de autoria. Entretanto, Smith aplicou o método do cruzamento entre fontes escritas e imagéticas. Tanto em suas análises, como em suas aulas e conferências, Smith percebia os objetos como constelações ou combinações de motivos, cada qual com sua história, séries e sequências de significados.

Smith estabeleceu razões de causa e efeito entre as obras de arte e utilizou documentos escritos para situar e validar historicamente suas proposições. Tais relações são percebidas nas explicações de um "desenvolvimento" respaldado por análises formais, isto é, esses tipos se enquadram dentro de padrões ou estilos e são dispostos evolutiva e cronologicamente. Sob essa perspectiva, as descrições minuciosas e detalhadas das obras de arte eram fundamentais tanto para aquelas que ainda estavam conservadas e poderiam ser vistas pessoalmente como as que 
desapareceram e eram conhecidas somente por meio de documentos. As relações entre tais obras, semelhanças, diferenças e filiações formais eram cruciais para a atribuição de autoria que não pudesse ser comprovada pela documentação.

Um exemplo dessa metodologia é percebido no artigo "Minas Gerais no Desenvolvimento da Arquitetura Colonial", publicado em 1937. Nesse estudo, Smith analisou aspectos formais da arquitetura religiosa mineira e suas semelhanças e diferenças com as construções do norte de Portugal. Pela análise documental e fotográfica, pela pesquisa bibliográfica e pela observação, interpretou os aspectos externos das construções, como a cúpula, a sacristia, a cruz, os sinos, as portadas, as fachadas e as torres. Analisou também elementos internos, como a ornamentação dos altares, das escadarias e das talhas. Ao discorrer sobre cada um desses elementos, listou os materiais dos quais foram feitos e, quando possível, abordou a autoria e inseriu sua análise em uma perspectiva mais ampla, ao fazer relações com os estilos europeus, especialmente de Portugal. Smith considerou os símbolos e signos presentes nas construções e buscou "resgatar" suas origens, identificando como eles foram mantidos ou transformados, no decorrer do tempo, em uma relação comparativa com Portugal.

Em Vitória, Espírito Santo, esteve por uma semana) e foi recebido por André Carloni. Visitou as cidades de Aracruz, Anchieta, Araçatuba e Nova Almeida, além de museus, arquivos e bibliotecas públicas. No Espírito Santo, conheceu, por intermédio de André Carloni, inúmeros pesquisadores, dentre eles, Olintho Aguirre, o historiador Eugênio de Assis e "outras pessoas que the pudessem prestar boas informações sobre assuntos históricos de nossa terra". Foi também recebido pelo Interventor Federal e "todas as autoridades do Estado do Espírito Santo". ${ }^{73}$

De 8 de dezembro de 1946 a 2 de março de 1947, Smith permaneceu no estado da Bahia, onde foi recepcionado por José Valladares, primeiro diretor do Museu de Arte da Bahia e responsável pelo prefácio do livro Arquitetura colonial. Como hóspede de José Valladares, teve contato diário com os "líderes da vida intelectual da cidade e conversas técnicas com arquivistas, bibliotecários e curadores de museus". ${ }^{74} \mathrm{Na}$ Bahia, visitou o Recôncavo, a Usina Vitória, da família Muniz de Aragão, Maragogipe, Engenho Velho, casa de Garcia D’Ávilae Paraguaçu. Nesta cidade, salientou a necessidade de conservação de edifícios com elementos indígenas, um dos poucos que restavam pelo estado. ${ }^{75}$

No Arquivo Histórico de Salvador, estabeleceu contato com Osvaldo Valente, diretor do Arquivo, que the facilitou a consulta de fotografias e de documentos. Nesse arquivo, pesquisou documentos sobre a primeira fábrica de vidros do Brasil e sobre a construção dos seminários dos jesuítas no sítio da saúde. Encontrou inúmeros ofícios mecânicos que mandaria para Rodrigo Melo Franco em forma de fichas. Encontrou contratos para a construção da lgreja de Santana e os trabalhos posteriores da 
76. Id. (1947d).

77. Andrade (1947).

78 Smith, (1947b).

79. Veio a..., (1947, p. 3).

80. Smith (1947e). sacristia. Descobriu um dos arquitetos do convento do Carmo e informações sobre os engenheiros da Aula Régia, responsáveis pelas plantas do Arquivo Militar, além de plantas e desenhos da cidade do Recife. Com essas fontes, pretendia escrever um artigo e publicar na revista do Sphan, mas não conseguiu dar continuidade, justificando da seguinte maneira: "estou aniquilado pelo calor e barulho da cidade e faltam-me livros de consulta necessários. $\bigcirc$ meu amigo compreenderá a minha atitude, nascida das circunstâncias especiais do ambiente". ${ }^{76}$

Encontrou, nesses arquivos, documentos sobre a arquitetura e mobiliário do século XVIII, fontes que, segundo ele, careciam de estudos mais aprofundados para que saíssem do anonimato. Para sistematizar a documentação existente nesses arquivos e facilitar o processo de pesquisa, sugeriu a Melo Franco a elaboração de um plano sistemático para leitura e reprodução dos documentos existentes nos arquivos militares, eclesiásticos e civis da Bahia. $\bigcirc$ objetivo desse levantamento seria "reconstruir e conhecer a história dos monumentos e dos artistas baianos". Rodrigo Melo Franco concordou com a sugestão de Smith, por acreditar que essa ação habilitaria a "reconstrução da história dos monumentos e dos artistas baianos". Concordou também com os nomes indicados por Smith, mas frisou: "como desconheço a documentação a ser inventariada e pesquisada, há necessidade de alguma pessoa idônea fazer um esboço do plano dos referidos trabalhos, para ser submetido ao estudo e a aprovação desta diretoria, antes de se iniciarem as atividades desejadas". 77 Não foram encontrados documentos que comprovem a realização ou não dessa ação; contudo, a partir da intenção de Smith em organizar os documentos, nota-se o diálogo do pesquisador com o Dphan, que também compartilhava o interesse de catalogação de documentação inédita a ser inserida nos arquivos da instituição. Durante a estada na Bahia, proferiu cinco conferências na Faculdade de Filosofia da Bahia, entre elas a "Arquitetura colonial nas três Américas" e, em 1947, foi nomeado professor emérito da Universidade da Bahia e sócio do Instituto Histórico e Geográfico. ${ }^{78}$

Em 2 de março de 1947, Smith desembarcou em Recife, Pernambuco, local do Brasil onde a arquitetura mais the encantou, além da "forte escola de personalidades locais". Seu objetivo era "visitar e fotografar os monumentos da cidade, os conventos franciscanos e os engenhos velhos".79 Em Recife, foi recebido por Edson Mota e Ayrton de Carvalho, que o acompanharam às excursões pela cidade a pedido de Melo Franco. Smith impressionou-se com a qualidade de boas imagens que fez em Pernambuco - cujas cópias seriam posteriormente enviadas à diretoria do Dphan - e com a limpeza das fachadas dos edifícios, em contraste com as paredes "sujas e estragadas" 80 da cidade de Salvador. Melo Franco não compartilhava da mesma opinião de Smith a respeito da primazia da arquitetura colonial pernambucana em relação a outras regiões do país, mas considerava que o patrimônio arquitetônico de 
Olinda, Recife e lgarassu era dotado de "um encanto e um pitoresco notáveis". ${ }^{81}$ Smith contou com a companhia do diplomata Joaquim de Sousa Leão Filho em visita a uma série de engenhos que ainda eram de sua família na região de Jaboatão. Sousa Leão, um colecionador de arte e fotografias de construções do período colonial ${ }^{82}$ apresentou Smith a outros colecionadores e especialistas em arte colonial.

Ainda em Recife, visitou as igrejas Madre de Deus, Espírito Santo, do Carmo, Santa Teresa e Conceição dos Militares, onde estudou a talha pernambucana e transcreveu cartas régias e livros de irmandade. Convidado pela prefeitura de Recife, fez um passeio de lancha pelo Rio Capibaribe até Apipucos, onde se situava a casa de Gilberto Freyre. Nos arquivos pesquisados, não foram encontradas correspondências entre Smith e Gilberto Freyre, mas eles se conheceram em 1939, na Conferência Bibliográfica, na Universidade de Michigan, onde presidiram uma conferência no evento. Smith participou da construção do Manual Bibliográfico de Estudos Brasileiros (MBEB) como autor da seção de arte.

Do Recife, Smith seguiu para Belém, último estado visitado antes de seu regresso para os Estados Unidos, em 11 de abril de 1947, onde foi recepcionado pelo representante do Dphan, Clemente $\mathrm{Cruz}_{1}^{83} \mathrm{em}$ uma curta estadia de quatro dias. Seu enfoque de pesquisa continuou na iconografia; dessa vez, investigou retratos e ilustrações do século XVIII, além dos manuscritos do naturalista português Alexandre Rodrigues Vieira (1756-1815), que, em sua "viagem filosófica", percorreu as regiões do Grão-Pará, Rio Negro, Mato Grosso e Cuiabá, entre 1783 e 1792.

Na região do Pará, os estudos de maior destaque foram sobre "Antônio José Landi, arquitecto italiano do século XVIII no Brasil", publicado nos Anais do Colóquio Internacional de Estudos Brasileiros, em 1960, e "El Palacio de los Gobernadores de Gran-Para", publicado em Buenos Aires, nos Anales del Instituto de Arte Americano e Investigaciones Estéticas, em 1951. Antes desse período, publicou notas esparsas sobre o arquiteto e escreveu uma carta enviada em 8 de setembro de 1948 a Rodrigo Melo Franco de Andrade, comentando sobre suas incursões nos arquivos portugueses. Dentre os inúmeros documentos encontrados, citou o grande álbum de Antônio Landi, do qual retirou inúmeras fotografias.

Robert Smith percorreu os rastros de Landi nos arquivos portugueses, visto que o arquiteto bolonhês prestou serviços à Coroa Portuguesa. Pela falta de técnicos em Portugal e à mestria de seu trabalho, foi convidado pelo rei para atuar como cartógrafo e participar de uma expedição para América do Sul, juntamente com espanhóis, holandeses, franceses e ingleses católicos, devido ao Tratado de Madri de 1750 (Ketle, 2010). Nessa expedição, Landi ficou responsável por registar as paisagens cartográficas na expedição sobre o Rio Negro, além de representar outras paisagens, como a fauna e flora da região amazônica.
81. Andrade, (1947).

82. Uma série de 37 fotografias da autoria de Robert Smith foram doadas para a Fundação Joaquim Nabuco. São fotografias de igrejas e conventos em seus detalhes arquitetônicos e decorativos de interior e exterior, nas cidades de Olinda e Recife (PE), Salvador (BA), São João del Rey, Tiradentes, Mariana, Sabará, Congonhas do Campo (MG). Essa coleção, que pertenceu ao diplomata Joaquim de Souza Leão Filho, foi desmembrada de um conjunto maior que serviu para estudos e pesquisas nos campos da História da Arte e da Diplomacia relativas ao Brasil.

83. Smith(1947a). 
84. Ibid. (1947a, p. 9)

85. Id. (1947c).

86. Ibid.

Ao percorrer as cidades brasileiras, Smith encontrou informações valiosas para seus estudos sobre o século XVIII, construções que "uma vez que sejam cuidadosamente estudadas, ajudarão enormemente a matar o fantasma do anonimato". ${ }^{84}$ Smith deixou o Brasil em 16 de abril de 1947 e, em carta a Rodrigo, expressou seu pesar em deixar o Brasil:

A ideia de sair do Brasil, este país que me acolheu com tanto carinho, com tanto amor, bruscamente, como se viaja de uma cidade para outra, me revolta. Deveria ser uma coisa preparada, a qual se chega aos poucos, calmamente e com muita meditação. Já vivencio certas nostalgias de dias, pessoas, lugares conhecidos que a gente costuma chamar de saudades. ${ }^{85}$

Por fim, Smith agradeceu a recepção oferecida no país:

Durante esses nove meses ninguém me recusou nada. Tudo quanto pedi me foi dado com a maior delicadeza e cortesia, principalmente com o memorável estágio que fiz na sede do Patrimônio. Nunca um viajante foi mais bem tratado, memoriado com tanta gentileza, com tanta atenção lisonjeira e não merecida quanto eu. Seria completamente inútil tentar agradecer ao amigo ou a outra pessoa das muitas que me tem ajudado. Deixarei em expressivo silêncio o assunto. ${ }^{86}$

Das pesquisas realizadas no Brasil durante os nove meses de sua segunda viagem, publicou os seguintes artigos: "Requena e o Japurá: algumas aquarelas do século XVIII sobre o Amazonas e outros rios" (1946), "Algumas vistas da Bahia colonial" (1948), "Arquitetura Jesuítica no Brasil" (1948), "Praia da Madeira no Recife: uma contribuição para a história econômica do Brasil" (1949), "Uma cadeia, uma capela e duas casas: desenhos de arquitetura Colonial Brasileira" (1949/1951), "A Brazilian Merchant's Exchange" (1949), "El Palácio de Los Gobernadores de Gran-Pará" (1951), "Arquitetura Colonial Baiana: alguns aspectos de sua história" (1951).

As viagens de Robert Smith por diversas regiões do país permitiram o contato do historiador com diferentes perspectivas e formas de "representação" da arquitetura colonial brasileira, saindo, dessa maneira, de um eixo fixo percebido na arquitetura mineira e nas obras de Aleijadinho. Smith estudou a arquitetura colonial paraense e da região Amazônica, com as obras de Antônio Landi e Francisco Requena, e, por conseguinte, hoje é uma das referências para o estudo da temática na região. No Espírito Santo, pesquisou as influências da arquitetura franciscana. Em São Luís do Maranhão, direcionou-se para os sobrados e para a arquitetura civil, ramo da arquitetura com pesquisas ainda incipientes naquele período. 
Em meio à articulação das pesquisas e das políticas culturais, as instituições brasileiras atuaram na mediação e no apoio a essas viagens, como foi o caso do Museu Nacional e de projetos de apoio a pesquisadores da Universidade de Columbia e ao Iphan, a partir da reunião por meio de publicações, de pesquisas e de intercâmbios entre pesquisadores nacionais e estrangeiros voltados principalmente para a temática colonial, como Robert Smith, Hanna Levy, Germain Bazin. $\bigcirc$ Iphan e Rodrigo Melo Franco de Andrade foram fundamentais para a articulação de Robert Smith no campo intelectual brasileiro e para os seus trânsitos entre diferentes cidades brasileiras. Assim sendo, conclui-se que o Iphan foi uma instituição central na mediação dessas pesquisas, na organização da produção acadêmica centrada na temática colonial, no intercâmbio entre pesquisadores e na articulação de políticas culturais voltadas para o patrimônio material.

Situadas além do colonialismo, as cidades e os cenários urbanos entendidos como local de embate, disputas, discussão e construção de parâmetros estéticos, patrimoniais e artísticos, foram responsáveis pelo agrupamento das temáticas pesquisadas por Smith. Essa constatação comprova a visão de que todas as manifestações artísticas estudadas por ele foram eminentemente urbanas. As cidades latino-americanas foram percebidas como um importante ponto de inserção de uma configuração cultural, um respeitado modelo urbano que Ángel Rama chamou de "cidade barroca". ${ }^{87}$ Portanto, a produção de Smith trata, em grande medida, da ambiência urbana, dos aspectos estéticos e artísticos percebidos nas cidades. Smith publicou inúmeros artigos e livros sobre as cidades brasileiras do século XVIII, período marcado por intensas transformações nos campos da ciência, da religião, da políitica, das artes e da estética. Na atualidade, essas fontes-textuais compõem um rico acervo fotográfico com imagens de sua autoria. Devido aos múltiplos interesses de pesquisa de Robert Smith, das intensas trocas acadêmicas estabelecidas para além do vasto arquivo pessoal acumulado, sua produção, muito mais do que apresentar respostas para o problema do colonial, aguça a visão para descobrir outros caminhos, novos personagens e temáticas, que certamente auxiliam na configuração da História da Arte brasileira em diálogo com as políticas culturais e o patrimônio. 


\section{REFERÊNCIAS}

FONTES IMPRESSAS

ANDRADE, Rodrigo Melo Franco de. [Ofício (Of. 1.120) de Rodrigo Melo Franco de Andrade ao Senhor Inspetor da Alfândega do Rio de Janeiro]. 30 jul. 1946. Disponível no Arquivo Central do Iphan, Seção Rio de Janeiro, Assuntos Internacionais - AA01/M065/P06/ Cx.0013/P.0060.

ANDRADE, Rodrigo Melo Franco. [Carta de Rodrigo Melo Franco a Robert Smith]. 4 fev. 1947. Disponível no Arquivo do Iphan, Seção Rio de Janeiro, Assuntos Internacionais - Cx.0013.

ANDRADE, Rodrigo Melo Franco de. [Carta de Rodrigo Melo Franco de Andrade a Pedro Guimarães Pinto]. 2 set. 1953. Disponível no Arquivo Central do Iphan, Seção Rio de Janeiro, Assuntos Internacionais - AA01/M065/P06/Cx.0013/P.0060.

CARLONI, André. [Carta de André Carloni a Rodrigo Melo Franco]. 9 dez. 1946. Disponível no Arquivo Central do Iphan, Seção Rio de Janeiro, Assuntos Internacionais, Cx.0013.

FONSECA, Edson Nery da. Breve nota sobre um poetisa norte americana no Brasil. A Manhã, Rio de Janeiro, p. 7-8, 30 out. 1941.

MARTINS, Judith. [Carta de Judith Martins a Robert Chester Smith]. 4 fev. 1947. Disponível no Arquivo Central do Iphan, Seção Rio de Janeiro, Assuntos Internacionais - Cx.0013.

NOTÍCIAS Literárias. Revista Ilustração Brasileira, Rio de Janeiro, ano XXIV, n. 137, p. 31, set. 1946.

SAIA, Luís. [Carta de Luís Saia a Rodrigo Melo Franco]. 25 set. 1946. Disponível no Arquivo Central do Iphan, Seção Rio de Janeiro, Assuntos Internacionais - Cx.0013/c.114/46.

SMITH, Robert Chester. [Carta de Robert Smith a Rodrigo Melo Franco de Andrade]. 19 abr. 1945. Disponível no Arquivo Central do Iphan, Seção Rio de Janeiro, Assuntos Internacionais - AA01/M065/P06/Cx.0013/P.0060.

SMITH, Robert Chester. [Carta de Robert Smith a Rodrigo Melo Franco]. 8 fev. 1947b. Disponível no Arquivo Central do Iphan, Seção Rio de Janeiro, Assuntos Internacionais - Cx.0013. 
SMITH, Robert Chester. [Carta de Robert Smith a Rodrigo Melo Franco]. 14 abr. 1947c. Disponível no Arquivo Central do Iphan, Seção Rio de Janeiro, Assuntos Internacionais - Cx.0013.

SMITH, Robert Chester. [Carta de Robert Smith para Melo Franco]. 12 fev. 1947d. Disponível no Arquivo do Iphan.

SMITH, Robert. [Carta de Robert Smith a Rodrigo Melo Franco]. 6 jul. 1947e. Disponível no Arquivo Central do Iphan, Seção Rio de Janeiro, Assuntos Internacionais, Cx.0013.

SMITH, Robert Chester. [Carta de Robert Smith a Rodrigo Melo Franco]. 12 mar. 1947e. Disponível no Arquivo Central do Iphan, Seção Rio de Janeiro, Assuntos Internacionais - Cx.0013.

SMITH, Robert Chester. [Carta manuscrita de Robert Smith a Rodrigo Melo Franco de Andrade]. 15 nov. 1953. Disponível no Arquivo Central do Iphan, Seção Rio de Janeiro, Assuntos Internacionais - AA01/M065/P06/Cx.0013/P.006.

SMITH, Robert Chester. [Homenagem de Robert Chester Smith a Rodrigo Melo Franco de Andrade]. 19-b. Disponível no Arquivo Central do Iphan, Seção Rio de Janeiro, Assuntos Internacionais, Cx.0013.

SMITH, Robert Chester. [Jornal Pequeno]. Jornal Pequeno, Recife, 14 abr. 1947j.

SOEIRO, Renato. [Carta de Renato Soeiro a Robert Smith]. 27 nov. 1969. Disponível na Fundação Calouste Gulbenkian.

VEIO A Pernambuco documentar nossos monumentos. Jornal Diário de Pernambuco, Recife, p. 3, 6 mar. 1947.

LIVROS, ARTIGOS E TESES

COSTA, Eduardo Augusto. Da fotografia à cultura visual: Arquivo Fotográfico e práticas de preservação do Iphan. Anais do Museu Paulista, São Paulo, v. 24, n. 3, p. 19-43, 2016. Disponível em: <https://bityli.com/hLQPP>.

GONÇALVES, Flávio. Recordando o professor Robert Smith. Belas Artes. Revista e Boletim da Academia Nacional de Belas Artes, Lisboa, n. 30, 1976. 
GONÇALVES, José Reginaldo. Os patrimônios e o tempo. Ciência Hoje. Revista de Divulgação Científica da SBPC. Suplemento Trimestral. Rio de Janeiro, abril 2010.

GOODWIN, Philip. Brazil Builds: architecture new and old 1652-1942. Nova Iorque: MoMA, 1943.

MELO, Sabrina Fernandes. Robert Chester Smith e o colonial na modernidade brasileira: entre história da arte e patrimônio. Tese (doutorado). Universidade Federal de Santa Catarina, Centro de Filosofia e Ciências Humanas. Programa de Pós Graduação em História. Florianópolis, 2018.

MILHEIRO, Ana Vaz. Um americano convertido ao barroco. In: Revista Ípsilon. Portugal,24 de Dezembro de 1999.

NEISTEIN, José. Robert Chester Smith e a Biblioteca do Congresso em Washington. In: SALA, Dalton et al. Robert Chester Smith (1912-1975): A investigação na História da Arte. Lisboa: Fundação Calouste Gulbenkian, 2000.

PEREIRA, Cecília Ribeiro. Robert Smith, diálogos e pesquisas no Brasil. In: Cadernos de Arquitetura e Urbanismo, v.21, n.28, $1^{\circ}$ sem. 2014.

RAMA, Ángel. A Cidade das Letras. São Paulo: Boitempo, 2015.

REIS FILHO, Nestor Goulart (Org.)Robert Smith e o Brasil: Arquitetura e Urbanismo (organização Nestor Goulart Reis Filho). Brasília,DF: Iphan, 2012.Volume I.

REIS FILHO, Nestor Goulart (Org.) Robert Smith e o Brasil: Cartografia e Iconografia (organização Nestor Goulart Reis Filho). Brasília, DF: Iphan, 2012.Volume II.

ROCHA, Ricardo. As linhas gerais da arquitetura e a ornamentação do convento de n. S. Da penha (es) por Robert C. Smith: uma análise comentada. In: COLÓQUIO BRASILEIRO DE HISTÓRIA DA ARTE, 9., 2014. Anais... Belo Horizonte, 2014.

ROSSATO, Luciana. A Lupa e o Diário: história natural, viagens científicas e relatos sobre a capitania de Santa Catarina (173-1822). Itajaí: Universidade do Vale do Itajaí, 2007.

SMITH, Robert Chester. A report of a trip through Brazil understaken in march 1937 under auspices of the American Council of Learned Societies. 1937a. Relatório.

SMITH, Robert Chester. A report of a expenditbures in Brazil from April 2 to July 5. 1937b. 
SMITH, Robert Chester. São Luiz do Maranhão. The Panamerican Traveler, Los Angeles, v. 1, n.1, p. 4-6, out./nov. 1938.

SMITH, Robert Chester. O Caráter da Arquitetura Colonial no Nordeste. Estudos Brasileiros, ano II, vol. 4, n. 10, p. 419-430, jan./fev., 1940c.

SMITH, Robert Chester. A visit of nine months to Brazil from july 1946 to april 1947. 1947a. Relatório.

SMITH, Robert Chester. Luso-Brazilian art in Latin American Studies. In: WILDER, Elizabeth (Ed.). Studies in Latin American Art. Washington: The American Council of Learned Societies, 1949.

SMITH, Robert Chester. Arquitetura Colonial. Salvador: Livraria Progresso, 1955.

TREBITSCH, Michel. Avant-propos: la chapelle, le clan et le microcosme. Les Cahiers de l'Instintut d'Histoire du Temps Présent. Sociabilités intellectuelle, Paris, n. 20, mar. 1992.

URIBARREN, Maria Sabina. Germain Bazin e o Iphan: redes de relações e projetos editoriais sobre o barroco brasileiro. In: Rev. CPC, v.13, n.25 especial, p.108-134, jan./set. 2018.

WOHL, Hellmut. Robert C. Smith e a História da Arte nos Estados unidos. In: SALA, Dalton. Robert C. Smith (1912-1975): A investigação na História da Arte. Lisboa: Fundação Calouste Gulbenkian, 2000.

WOOD, Roosell. Robert Smith: Investigador e Historiador. SALA, Dalton. Robert C. Smith (1912-1975): A investigação na História da Arte. Lisboa: Fundação Calouste Gulbenkian, 2000.

Artigo apresentado em: 10/8/2019. Aprovado em: 9/10/2020.

\section{(cc) BY}

All the contents of this journal, except where otherwise noted, is licensed under a Creative Commons Attribution Licens 